\title{
Long-term patterns of mass loss during the decomposition of leaf and fine root litter: an intersite comparison
}

\author{
MARK E. HARMON*, WHENDEE L. SILVER†, BECKY FASTH*, HUA CHEN*, INGRID C. \\ BURKE $\ddagger$, WILLIAM J. PARTON§, STEPHEN C. HART, W WLLIAM S. CURRIE\| and LIDET ${ }^{1}$ \\ *Department of Forest Science, Oregon State University, 321 Richardson Hall, Corvallis, OR 97331, USA, †Department of \\ Environmental Science, Policy, and Management, Ecosystem Sciences Division, University of California, Berkeley, CA 94720, USA, \\ $\ddagger$ Department of Forest, Rangeland, and Watershed Stewardship, Colorado State University, Fort Collins, CO 80523, USA, §Natural \\ Resource Ecology Laboratory, Colorado State University, Fort Collins, CO 80523, USA, -School of Forestry and Merriam-Powell \\ Center for Environmental Research, Northern Arizona University, PO Box 15018, Flagstaff, AZ 86011-5018, USA, ||School of \\ Natural Resources E Environment, Dana Bldg., 430 E. University, University of Michigan, Ann Arbor, MI 48109-1115, USA
}

\begin{abstract}
Decomposition is a critical process in global carbon cycling. During decomposition, leaf and fine root litter may undergo a later, relatively slow phase; past long-term experiments indicate this phase occurs, but whether it is a general phenomenon has not been examined. Data from Long-term Intersite Decomposition Experiment Team, representing 27 sites and nine litter types (for a total of 234 cases) was used to test the frequency of this later, slow phase of decomposition. Litter mass remaining after up to 10 years of decomposition was fit to models that included (dual exponential and asymptotic) or excluded (single exponential) a slow phase. The resultant regression equations were evaluated for goodness of fit as well as biological realism. Regression analysis indicated that while the dual exponential and asymptotic models statistically and biologically fit more of the litter type-site combinations than the single exponential model, the latter was biologically reasonable for $27-65 \%$ of the cases depending on the test used. This implies that a slow phase is common, but not universal. Moreover, estimates of the decomposition rate of the slowly decomposing component averaged $0.139-0.221$ year $^{-1}$ (depending on method), higher than generally observed for mineral soil organic matter, but one-third of the faster phase of litter decomposition. Thus, this material may be slower than the earlier phases of litter decomposition, but not as slow as mineral soil organic matter. Comparison of the long-term integrated decomposition rate (which included all phases of decomposition) to that for the first year of decomposition indicated the former was on average $75 \%$ that of the latter, consistent with the presence of a slow phase of decomposition. These results indicate that the global store of litter estimated using short-term decomposition rates would be underestimated by at least one-third.
\end{abstract}

Keywords: decay, decomposition, fine roots, leaves, litter, long-term study, rate constant, stable fraction

Received 23 May 2008; revised version received 18 September 2008 and accepted 1 October 2008

\section{Introduction}

Plant litter in the form of dead leaves and roots is a source of soil organic matter, the largest terrestrial store of carbon (Post et al., 1982). The current size of this store

Correspondence: Mark E. Harmon, fax + 1541737 1393,

e-mail: mark.harmon@oregonstate.edu

${ }^{1}$ See Table 1 for the list of 27 LIDET team members and its fate under global environmental change requires insight into the long-term temporal pattern of litter decomposition (Kirschbaum, 2000). Little is known about long-term patterns of decomposition, in part, because few experiments have tracked the process from fresh litter to the formation of highly decomposed material. Nearly 4000 papers have been published on the topic of litter decomposition (Institute of Scientific Information Web of Science), but few extend beyond a 
given ecosystem type for more than several years (e.g. Gholz et al., 2000; Trofymow et al., 2002). The vast majority of experiments have lasted 1-2 years (Swift et al., 1979; Melillo et al., 1984; Vogt et al., 1986; Silver \& Miya, 2001) yielding many insights into the temporal pattern early in decomposition (Olson, 1963; Howard \& Howard, 1974) as well as the controls on initial mass loss such as initial litter quality (Minderman, 1968; Bunnell \& Tait, 1977; Fogel \& Cromack, 1977; Melillo et al., 1982), invertebrates (Kurcheva, 1960; Witkamp \& Olson, 1963; Witkamp \& Crossley, 1966), and environmental variables such as temperature and moisture (Bunnell et al., 1977; Meentemeyer, 1978; Jansson \& Berg, 1985; Yahdjian et al., 2006). However, 2 years is not enough time in most environments to reveal dynamics in the later phases of this key ecosystem process.

Previous investigators have proposed conceptual models of decomposition with at least two distinct phases, although ideas have differed on the mechanisms distinguishing the phases and the degree of recalcitrance or stability of material in the later phases. Coûteaux et al. (1995) proposed a two-phase conceptual model in which Phase I was dominated by the loss of soluble and relatively labile compounds from litter, including some of the cellulose present. In Phase II, decomposition continued, but with a strong control exerted by lignin. In contrast, Melillo et al. (1989) and Aber et al. (1990) proposed a two-phase conceptual model in which the material in Phase II was similar, if not identical to soil organic matter and was termed 'stable' over a time-span of approximately a decade.

The gradually slowing absolute rate of mass loss from decaying litter over time can be captured by a firstorder or exponential decay function [Eqn (1)] where $M_{t}$ is litter mass at time $t, M_{0}$ is initial litter mass, and $k$ is the rate constant of loss

$$
M_{t}=M_{0} \mathrm{e}^{-k t},
$$

However, the long-term studies (e.g. Aber et al., 1990; Magill \& Aber, 1998; Berg et al., 2001; Trofymow et al., 2002; Moore et al., 2005) that have been conducted suggest that in later stages rates of decomposition slow to a degree beyond that captured by a single-exponential decomposition curve. For litters high in soluble and labile fractions, a very rapid phase of decomposition may also occur within days to weeks of litter formation (Harmon et al., 1990; Currie \& Aber, 1997). Exponential rate constants of mass loss (i.e. the proportion lost per unit time) of the soluble and labile fractions during this phase may exceed 10 year $^{-1}$, indicating this material is lost within a few months. During the following phase, which dominates the first few years for many litter types in temperate environments, structural polymers are degraded. While there is considerable range in the speed at which these materials are degraded, exponential rate constants of $0.1-5$ year $^{-1}$ are typical (Singh \& Gupta, 1977; Swift et al., 1979; Vogt et al., 1986). As these polymers are degraded, residual and newly formed recalcitrant materials begin to dominate the decomposition process. The size and rate this late phase pool decomposes are not well established and may have a great deal of variability (Berg \& McClaugherty, 2003). In some cases, slow phase decomposition rates appear to be very low (Berg et al., 1984). Carbon isotope studies suggest that rate constants for highly decomposed soil organic matter, i.e. material that is generally complexed with mineral material, are typically below 0.01 year $^{-1}$ (Gaudinski et al., 2000; Trumbore, 2000). Modeling analysis of the forest floor in northern hardwoods forests of the northeastern United States suggests that if Phase II sensu Aber et al. (1990), starts when 20\% of the original litter mass remained, then a rate constant of 0.017 year $^{-1}$ would be needed to match the measured forest floor mass (Currie \& Aber, 1997).

A major gap to studying decomposition is the lack of a careful assessment of the philosophy supporting and consequences of choosing certain mathematical models describing the course of decomposition. The single negative exponential model [Eqn (1)] has been most commonly used to determine the decomposition rate of litter. This model often does not capture the initial very rapid loss phase adequately (Blair et al., 1990; Chen et al., 2002), but has worked remarkably well for the majority of data from short-term experiments. If decomposition follows this simple exponential pattern, then predicting temporal patterns in the later stages of decomposition by extrapolation is possible. However, the long-term data that exist indicate a relatively slow phase of decomposition is eventually reached (Lousier \& Parkinson, 1978, 1979; Berg et al., 1984; Edmonds, 1984; McClaugherty et al., 1985; Chen et al., 2002) and sometimes an asymptote in mass being reached implying extremely slow decomposition (Wardle et al., 1997; Berg et al., 2001).

There are two alternatives to the single negative exponential equation: the multiple (or in the most simple case the dual) exponential; and the negative exponential with an asymptote (Howard \& Howard, 1974; Wieder \& Lang, 1982). Both equations capture the transition from rapid to slow decomposition, although the asymptotic equation implies a steady accumulation of partially decomposed litter (because the litter represented by the asymptote does not decompose). In addition to deriving separate decomposition rates for each of the multiple fractions (e.g. the 'fast' and 'slow' fractions), these equations require estimating the initial proportions of these fractions. Previous studies on hardwood species in the northeastern United States indi- 
cated that approximately $20 \%$ of the initial litter was formed of slowly decomposing material (Aber et al., $1990)$. Berg $(2000 a, b)$ found that it varied from $6 \%$ to $47 \%$ of initial forest litter mass, depending on the amount of nitrogen present. The degree this slowly decomposing fraction is initially present or created by the many biological and chemical reactions that we term 'decomposition' is still under debate. While some litter types apparently enter a phase in which decomposition rates are relatively low, it is unclear whether this is a general pattern; if so, the degree that it is influenced by substrate quality, environment, and their interactions needs to be elucidated.

This paper provides a general overview of Long-term Intersite Decomposition Experiment Team (LIDET), a study that generated a dataset that we use to test the generality of a late, slow phase of decomposition (Moorhead et al., 1999; Gholz et al., 2000). Our specific objectives in this paper are: (1) to examine a series of mathematical models to test how well they statistically fit observations and how well they conformed to biological expectations; (2) to evaluate the generality of a slow phase and the fraction of the litter involved; and (3) to provide estimates of how fast this material decomposed.

\section{The LIDET study}

\section{Background}

The data used in this study were from the LIDET, a project which carried out a 10-year field study with the primary objective of testing the degree to which substrate quality and climate control the long-term carbon and nitrogen dynamics of decomposing leaf and fine root litter (Table 1). LIDET employed a standardized methodology at a large number of sites (27) to examine decomposition patterns within the first decade of decomposition of 30 species of litter. In addition to characterizing the climate during the course of the experiments, the chemical nature of the material used in the experiment was described using a wide range of carbon fractions and nutrient elements. LIDET therefore represents one of the few comprehensive, long-term or large-scale datasets from which to develop generalizable patterns.

\section{General experimental design}

Three experiments were conducted by LIDET: (1) a comparison of long-term leaf and fine root decomposition to examine the effect of substrate quality and climate on patterns of long-term decomposition and nitrogen accumulation in above- and below-ground fine litter, (2) a comparison of leaf decomposition with and without macroinvertebrates, and (3) a comparison of environmental influences on wood decomposition above- and below-ground using wooden dowels as a common substrate. The major factors considered in the leaf and fine root experiment, the focus of this paper, were site, species of litter, and time. There were 27 sites, representing a wide array of moisture and temperature conditions, at which the experiments were installed (Table 1, Fig. 1). Each site was characterized in terms of location (i.e. latitude and longitude), elevation, climate [precipitation, temperature, Actual Evapotranspiration (AET), potential evapotranspiration, Climate Decomposition Index (CDI); see Adair et al., 2008], and vegetation (biome type and specific vegetation cover). The sites span a wide array of ecosystem types from tundra to warm desert to shortgrass steppe to moist tropical forest. Climate data were taken from measurements at the site or from nearby climatic stations. Precipitation ranged from 24 to $409 \mathrm{~cm} \mathrm{yr}^{-1}$ and mean annual air temperature ranged from -7 to $26^{\circ} \mathrm{C}$ (Fig. 2). Nine types of 'standard' litters were sent to each of the 27 sites including: three types of fine roots (graminoid, hardwood, and conifer) and six types of leaf litter that ranged in AUF/nitrogen ratio from 5 to 50 (Table 2, Fig. 3). Samples were collected 10 times and there were four replicates for each species, site, and time. In addition to the standard litters, each site is represented by a 'wildcard' litter that appeared at one site for each sample collection. The purpose of the wildcard species was to verify the predictions from the standard species. There were also four replicates for each wildcard species, site, and time.

\section{Materials and methods}

\section{Field and laboratory}

Fresh leaf and fine roots for the standard litters was gathered from five of the 27 LIDET sites. The leaves were collected by a range of methods, ranging from collection of senescent leaves from trees (the primary method), to collecting freshly fallen litter from the ground, to removing green foliage (used at one of the tropical sites). Fine roots ( $<2 \mathrm{~mm}$ diameter) were collected by either excavating surface roots and washing or collecting material exposed along stream banks. All litter was air dried at room temperature before shipment to Oregon State University except materials those from Luquillo which were oven-dried at $50^{\circ} \mathrm{C}$ to halt decomposition.

All the litterbags used were $20 \mathrm{~cm} \times 20 \mathrm{~cm}$ and filled with an air-dried mass of $10 \mathrm{~g}$ leaves and $5-7 \mathrm{~g}$ of fine roots. Each bag was identified with a unique number 
Table 1 General characteristics of sites used in the LIDET study and the list of LIDET team members

\begin{tabular}{|c|c|c|c|c|c|c|c|c|c|c|}
\hline Site & Code & Latitude & Longitude & Biome type & MAP & MAT & AET & PET & Elev & $\begin{array}{l}\text { LIDET team } \\
\text { member }\end{array}$ \\
\hline $\begin{array}{l}{ }^{*} \mathrm{H} . \mathrm{J} \text { Andrews } \\
\text { Experimental Forest, } \\
\text { Oregon }\end{array}$ & AND & $44^{\circ} 14^{\prime} \mathrm{N}$ & $122^{\circ} 11^{\prime} \mathrm{W}$ & $\begin{array}{l}\text { Temperate Conifer } \\
\text { Forest }\end{array}$ & 230.9 & 8.6 & 76.4 & 98.2 & 500 & M. Harmon \\
\hline *Arctic Lakes, Alaska & ARC & $68^{\circ} 38^{\prime} \mathrm{N}$ & $149^{\circ} 34^{\prime} \mathrm{W}$ & Tundra & 32.7 & -7.0 & 28.4 & 42.3 & 760 & J Laundre \\
\hline $\begin{array}{l}\text { Barro Colorado } \\
\text { Island, Panama }\end{array}$ & BCI & $9^{\circ} 10^{\prime} \mathrm{N}$ & $79^{\circ} 51^{\prime} \mathrm{W}$ & $\begin{array}{l}\text { Humid Tropical } \\
\text { Seasonal Forest }\end{array}$ & 269.2 & 25.6 & 136.8 & 151.7 & 30 & J. Wright \\
\hline $\begin{array}{l}\text { *Bonanza Creek } \\
\text { Experimental Forest, } \\
\text { Alaska }\end{array}$ & $\mathrm{BNZ}$ & $64^{\circ} 45^{\prime} \mathrm{N}$ & $148^{\circ} 00^{\prime} \mathrm{W}$ & Boreal Forest & 40.3 & -5.0 & 36.0 & 57.6 & 300 & J. Yarie \\
\hline $\begin{array}{l}\text { Blodgett Research } \\
\text { Forest, California }\end{array}$ & BSF & $38^{\circ} 52^{\prime} \mathrm{N}$ & $105^{\circ} 38^{\prime} \mathrm{W}$ & $\begin{array}{l}\text { Temperate Conifer } \\
\text { Forest }\end{array}$ & 124.4 & 14.4 & 75.3 & 109.7 & 1300 & S. Hart \\
\hline $\begin{array}{l}{ }^{*} \text { Cedar Creek } \\
\text { Natural History } \\
\text { Area,Minnesota }\end{array}$ & CDR & $45^{\circ} 24^{\prime} \mathrm{N}$ & $93^{\circ} 12^{\prime} \mathrm{W}$ & $\begin{array}{l}\text { Temperate } \\
\text { Woodland/Humid } \\
\text { Grassland }\end{array}$ & 82.3 & 5.5 & 73.3 & 102.6 & 230 & D. Wedin \\
\hline $\begin{array}{l}{ }^{*} \text { Central Plains } \\
\text { Experimental Range, } \\
\text { Colorado }\end{array}$ & CPR & $40^{\circ} 49^{\prime} \mathrm{N}$ & $104^{\circ} 46^{\prime} \mathrm{W}$ & $\begin{array}{l}\text { Temperate } \\
\text { Shortgrass }\end{array}$ & 44.0 & 8.9 & 43.0 & 120.2 & 1650 & I. Burke \\
\hline $\begin{array}{l}{ }^{*} \text { Coweeta } \\
\text { Hydrological } \\
\text { Laboratory, North } \\
\text { Carolina }\end{array}$ & CWT & $35^{\circ} 00^{\prime} \mathrm{N}$ & $83^{\circ} 30^{\prime} \mathrm{W}$ & $\begin{array}{l}\text { Temperate } \\
\text { Deciduous Forest }\end{array}$ & 190.6 & 12.5 & 117.3 & 135.3 & 700 & B. Clinton \\
\hline $\begin{array}{l}\text { Guanica State Forest, } \\
\text { Puerto Rico }\end{array}$ & GSF & $17^{\circ} 57^{\prime} \mathrm{N}$ & $65^{\circ} 52^{\prime} \mathrm{W}$ & Dry Tropical Forest & 50.8 & 26.3 & 50.2 & 142.2 & 80 & A. Lugo \\
\hline $\begin{array}{l}{ }^{*} \text { Hubbard Brook } \\
\text { Experimental Forest, } \\
\text { New Hampshire }\end{array}$ & HBR & $43^{\circ} 56^{\prime} \mathrm{N}$ & $71^{\circ} 45^{\prime} \mathrm{W}$ & $\begin{array}{l}\text { Temperate } \\
\text { Deciduous Forest }\end{array}$ & 139.6 & 5.0 & 71.2 & 81.7 & 300 & T. Fahey \\
\hline $\begin{array}{l}\text { *Harvard Forest, } \\
\text { Massachusetts }\end{array}$ & HFR & $42^{\circ} 40^{\prime} \mathrm{N}$ & $72^{\circ} 15^{\prime} \mathrm{W}$ & $\begin{array}{l}\text { Temperate } \\
\text { Deciduous Forest }\end{array}$ & 115.2 & 7.1 & 85.1 & 104.1 & 335 & J. Melillo \\
\hline $\begin{array}{l}\text { *Jornada } \\
\text { Experimental Range, } \\
\text { New Mexico }\end{array}$ & JRN & $32^{\circ} 30^{\prime} \mathrm{N}$ & $106^{\circ} 45^{\prime} \mathrm{W}$ & Warm Semi-desert & 29.8 & 14.6 & 29.2 & 166.6 & 1410 & J. Anderson \\
\hline Juneau, Alaska & JUN & $58^{\circ} 00^{\prime} \mathrm{N}$ & $134^{\circ} 00^{\prime} \mathrm{W}$ & $\begin{array}{l}\text { Temperate Conifer } \\
\text { Forest }\end{array}$ & 287.8 & 4.4 & 49.5 & 54.4 & 100 & M. McClellan \\
\hline $\begin{array}{l}\text { *Kellogg Biological } \\
\text { Station, Michigan }\end{array}$ & KBS & $42^{\circ} 24^{\prime} \mathrm{N}$ & $85^{\circ} 24^{\prime} \mathrm{W}$ & Agro Ecosystem & 81.1 & 9.0 & 70.6 & 100.7 & 288 & S. Halstead \\
\hline $\begin{array}{l}{ }^{*} \text { Konza Prairie } \\
\text { Research Natural } \\
\text { Area, Kansas }\end{array}$ & KNZ & $39^{\circ} 05^{\prime} \mathrm{N}$ & $96^{\circ} 35^{\prime} \mathrm{W}$ & Temperate Tallgrass & 79.1 & 12.8 & 74.7 & 125.0 & 366 & J. Blair \\
\hline $\begin{array}{l}\text { La Selva Biological } \\
\text { Station, Costa Rica }\end{array}$ & LBS & $10^{\circ} 00^{\prime} \mathrm{N}$ & $83^{\circ} 00^{\prime} \mathrm{W}$ & $\begin{array}{l}\text { Humid Tropical } \\
\text { Forest }\end{array}$ & 409.9 & 25.0 & 169.9 & 177.3 & 35 & P. Sollins \\
\hline $\begin{array}{l}\text { *Luquillo } \\
\text { Experimental Forest, } \\
\text { Puerto Rico }\end{array}$ & LUQ & $18^{\circ} 19^{\prime} \mathrm{N}$ & $65^{\circ} 49^{\prime} \mathrm{W}$ & $\begin{array}{l}\text { Humid Tropical } \\
\text { Forest }\end{array}$ & 336.3 & 23.0 & 123.4 & 125.9 & 350 & J. Lodge \\
\hline $\begin{array}{l}\text { Loch Vale Watershed, } \\
\text { Colorado }\end{array}$ & LVW & $40^{\circ} 17^{\prime} \mathrm{N}$ & $105^{\circ} 39^{\prime} \mathrm{W}$ & Boreal Forest & 109.6 & 1.6 & 85.1 & 108.3 & 3160 & J. Baron \\
\hline $\begin{array}{l}\text { Monte Verde, } \\
\text { Costa Rica }\end{array}$ & MTV & $10^{\circ} 18^{\prime} \mathrm{N}$ & $84^{\circ} 48^{\prime} \mathrm{W}$ & $\begin{array}{l}\text { Tropical Elfin Cloud } \\
\text { Forest }\end{array}$ & 268.5 & 17.7 & 108.4 & 116.6 & 1550 & N. Nadkarni \\
\hline $\begin{array}{l}\text { North Inlet (Hobcaw } \\
\text { Barony), South } \\
\text { Carolina }\end{array}$ & NIN & $33^{\circ} 30^{\prime} \mathrm{N}$ & $79^{\circ} 13^{\prime} \mathrm{W}$ & Wetland & 149.1 & 18.1 & 120.6 & 145.6 & 2 & J. Morris \\
\hline $\begin{array}{l}\text { *North Temperate } \\
\text { Lakes, Trout Lake } \\
\text { Station, Wisconsin }\end{array}$ & NLK & $46^{\circ} 00^{\prime} \mathrm{N}$ & $89^{\circ} 40^{\prime} \mathrm{W}$ & $\begin{array}{l}\text { Temperate } \\
\text { Deciduous Forest }\end{array}$ & 67.7 & 4.4 & 64.9 & 88.4 & 500 & T. Gower \\
\hline
\end{tabular}


Table 1 Continued

\begin{tabular}{|c|c|c|c|c|c|c|c|c|c|c|}
\hline Site & Code & Latitude & Longitude & Biome type & MAP & MAT & AET & PET & Elev & $\begin{array}{l}\text { LIDET team } \\
\text { member }\end{array}$ \\
\hline $\begin{array}{l}\text { *Niwot Ridge/Green } \\
\text { Lakes Valley, } \\
\text { Colorado }\end{array}$ & NWT & $40^{\circ} 03^{\prime} \mathrm{N}$ & $105^{\circ} 37^{\prime} \mathrm{W}$ & Tundra & 124.9 & -3.7 & 64.7 & 75.6 & 3650 & J. Baron \\
\hline $\begin{array}{l}\text { Olympic National } \\
\text { Park, Washington }\end{array}$ & OLY & $47^{\circ} 50^{\prime} \mathrm{N}$ & $122^{\circ} 53^{\prime} \mathrm{W}$ & $\begin{array}{l}\text { Temperate Conifer } \\
\text { Forest }\end{array}$ & 153.1 & 10.0 & 79.4 & 104.4 & 150 & R. Edmonds \\
\hline $\begin{array}{l}{ }^{*} \text { Sevilleta National } \\
\text { Wildlife Refuge, New } \\
\text { Mexico }\end{array}$ & SEV & $34^{\circ} 29^{\prime} \mathrm{N}$ & $106^{\circ} 40^{\prime} \mathrm{W}$ & Warm Semi-desert & 25.4 & 16.0 & 25.2 & 160.2 & 1572 & C. White \\
\hline $\begin{array}{l}\text { Santa Margarita } \\
\text { Ecological Reserve, } \\
\text { California }\end{array}$ & SMR & $33^{\circ} 30^{\prime} \mathrm{N}$ & $117^{\circ} 45^{\prime} \mathrm{W}$ & Annual Grassland & 24.0 & 16.4 & 23.6 & 186.0 & 500 & P. Zedler \\
\hline $\begin{array}{l}\text { University of Florida, } \\
\text { Florida }\end{array}$ & UFL & $29^{\circ} 45^{\prime} \mathrm{N}$ & $82^{\circ} 30^{\prime} \mathrm{W}$ & $\begin{array}{l}\text { Temperate Conifer } \\
\text { Forest }\end{array}$ & 123.8 & 21.0 & 116.6 & 162.1 & 35 & H. Gholz \\
\hline $\begin{array}{l}\text { *Virginia Coast } \\
\text { Reserve, Virginia }\end{array}$ & VCR & $37^{\circ} 30^{\prime} \mathrm{N}$ & $75^{\circ} 40^{\prime} \mathrm{W}$ & Wetland & 113.8 & 15.0 & 99.3 & 121.5 & 0 & L. Blum \\
\hline
\end{tabular}

LIDET, Long-term Intersite Decomposition Experiment Team; MAP, mean annual precipitation (cm); MAT, mean annual temperature $\left({ }^{\circ} \mathrm{C}\right)$; AET, actual evapotranspiration $(\mathrm{cm})$; PET, potential evapotranspiration $(\mathrm{cm})$; elev, elevation $(\mathrm{m})$. Climatic data are for the duration of the experiment. Asterisks denote that the site is a member of the Long Term Ecological Research (LTER) network.

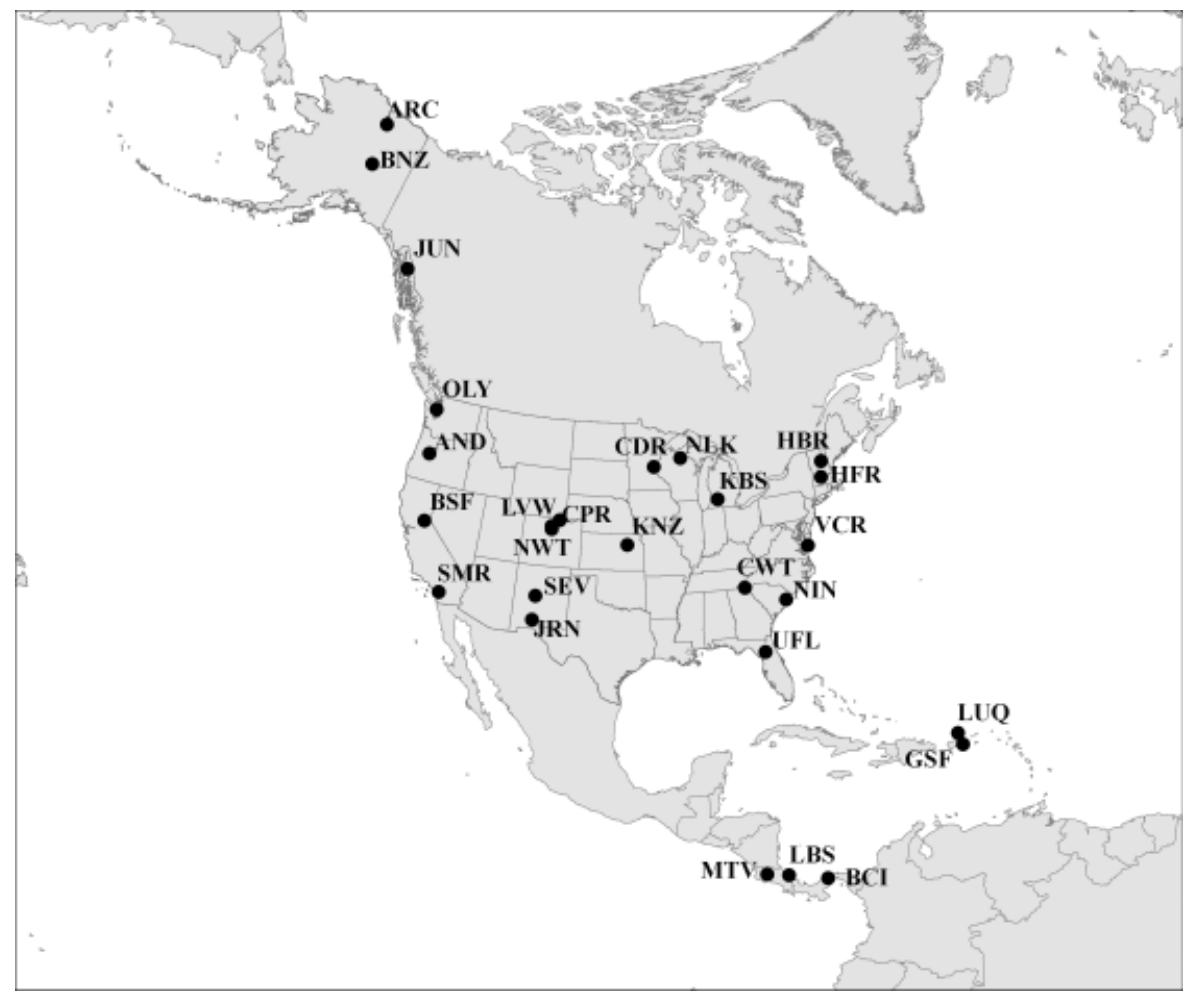

Fig. 1 Location of the Long-term Intersite Decomposition Experiment Team (LIDET) study sites.

embossed on an aluminum tag. The bag openings were sealed with six Monel staples. The initial air-dry weight, calculated oven-dry weight, species, site, and replicate number for each litterbag were recorded before placement in the field. Subsamples of litter material were taken to determine the air-dry to oven-dry conversion factor and the initial chemistry of the litter. These were taken at the start and end of each weighing session, with an additional sample taken in the middle of longer sessions. The standard deviation of the air dried litter moisture content for all 120 samples was $2 \%$, with a standard error of $0.002 \%$. Two types of bags were used 


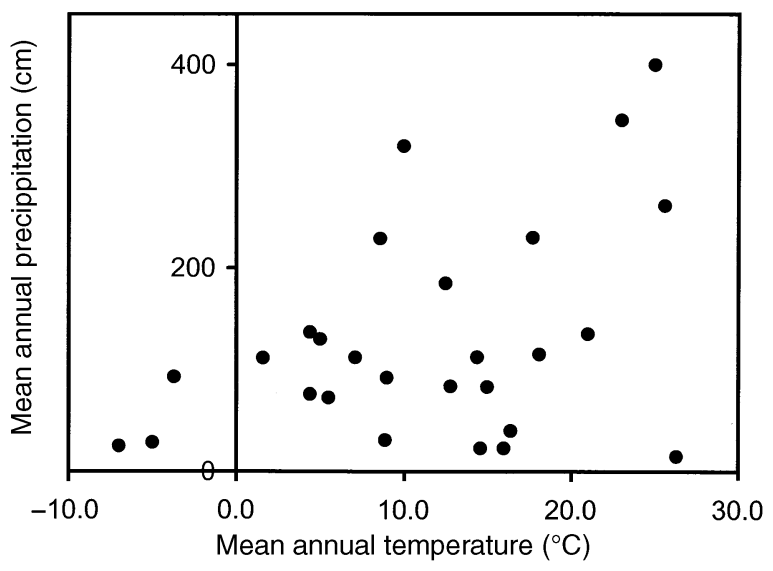

Fig. 2 Range of mean climate conditions for the sites used in Long-term Intersite Decomposition Experiment Team (LIDET).

in this experiment. For the long-term leaf litter experiment, the bags had a top mesh of $1 \mathrm{~mm}$ nylon and a bottom of $55 \mu \mathrm{m}$ Dacron. The bags used for fine roots were made entirely of $55 \mu \mathrm{m}$ Dacron mesh.

Samples were placed in the field during fall of 1990 or 1991 by each of the participating sites. Four separate locations at each site were selected to represent the range of typical conditions. At each of these locations, 10 sets of litter bags were placed. Each set of 10 bags to be collected at a given time and location were tethered to a cord; these sets of bags were laid out in parallel lines in a random order. Leaf litter bags were placed on the ground surface. Fine root bags were placed within the top $20 \mathrm{~cm}$ of the soil by cutting into the soil with a shovel at a $45^{\circ}$ angle, sliding the root bag into the cut, and then firmly pressing the overlying soil onto the bag.

All sites, other than the tropical ones, collected the fine litter on an annual basis for a 10-year period. For tropical sites (Barro Colorado Island, La Selva, Luquillo, and Monteverde) sampling was conducted every 3-6 months. Once the litter or dowels were collected, the fresh and oven-dry weight was determined and recorded. Samples were oven dried in paper bags at $55^{\circ} \mathrm{C}$ until the mass was stable. The samples were then sent to Oregon State University for preparation for chemical analysis as well as reweighing of selected samples for data quality checks. The contents of each litterbag were ground separately and stored in plastic vials labeled to identify the species, site, and time the sample was taken. Samples were also pooled by species, site, and time to provide samples for wet chemical and near infrared (NIR) analysis.

Nitrogen and carbon concentration was determined on a Leco C/N/S-2000 Macro Analyzer (Leco Inc, St Joseph, MI, USA). Ash concentration was determined by heating in a muffle furnace at $450{ }^{\circ} \mathrm{C}$ for $8 \mathrm{~h}$. Analysis of carbon fractions for undecomposed litter followed the methods of McClaugherty et al. (1985) and Ryan et al. (1990). Nonpolar extractives, (i.e. soluble fats, waxes, and oils) were removed using dichloromethane (Tappi, 1976; Bridson, 1985). Simple sugars and water soluble phenolics were removed with hot water (Tappi, 1981). Simple sugars were determined with the phenolsulfuric acid assay (DuBois et al., 1956). Water soluble phenolics were determined using the Folin-Denis procedure (Hagerman, 1988; Haslam, 1989). The acid unhydrolysable fraction, traditionally called lignin, was determined by hydrolyzing extractive-free material with sulfuric acid and weighing the residue (Effland, 1977; Obst \& Kirk, 1988). Hydrolysates were analyzed for carbohydrate content using the phenol-sulfuric acid assay (DuBois et al., 1956).

\section{Mathematical models}

The data used for this analysis were derived from the LIDET study (Moorhead et al., 1999, Gholz et al., 2000) and we only analyzed data for the 'standard litters' that were placed at all of the 27 sites for each sample time (the raw data and detailed results of the analysis can be found at http://www.fsl.orst.edu/lter/research/ intersite/lidet.htm). We examined how well the data from all sites fit simple mathematical models and the question of whether a 'slow' fraction formed during long-term decomposition by comparing three types of regression models: (1) a simple negative exponential, (2) a negative exponential with an asymptote, and (3) a dual negative exponential model (Wieder \& Lang, 1982). Our intent was not to find the single 'best' equation to use or test the best simulation model. Rather, we compared the predictions of these regression models to the observed data and to each other to find cases where a model would apply and if the models predicted similar patterns. Each model is based on different assumptions about the decomposition processes, and because of this, the cases where each model did not apply implies the assumptions were not valid. Both the negative exponential with an asymptote, and dual negative exponential model imply a later, slower decomposition phase, although the asymptotic model implies a rate constant equal to zero is eventually reached.

The first regression model used (Model 1) was a simple negative exponential

$$
M_{t 1}=M_{01} \times \exp \left(-k_{1} \times t\right),
$$

where $M_{t 1}$ is the percent ash-free mass remaining, $M_{01}$ is the initial ash-free mass, $t$ is time in years, and $k_{1}$ is the decomposition rate constant in year ${ }^{-1}$. This model is the one most commonly used to determine the decom- 
1326 M. E. HARMON et al.

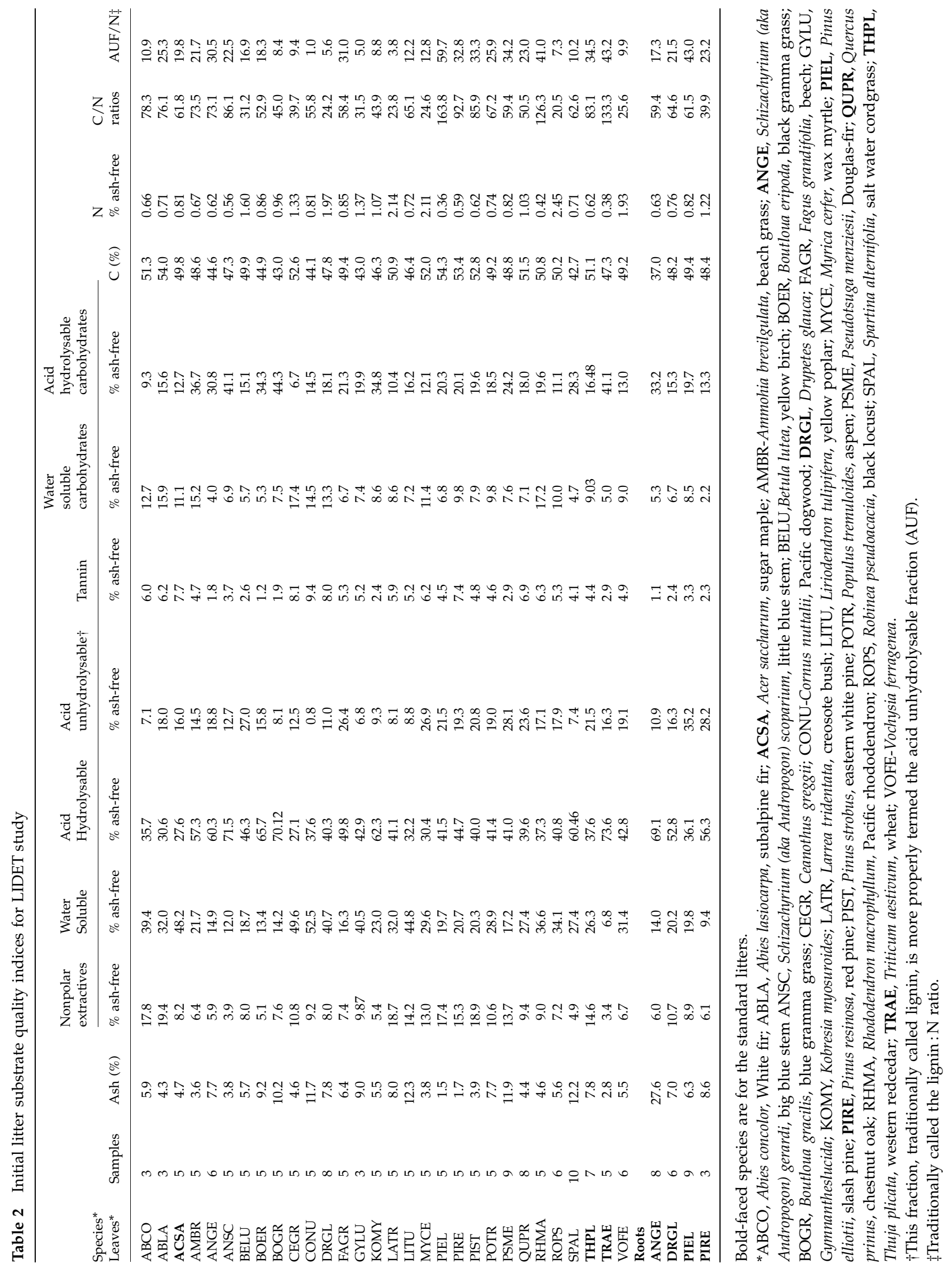




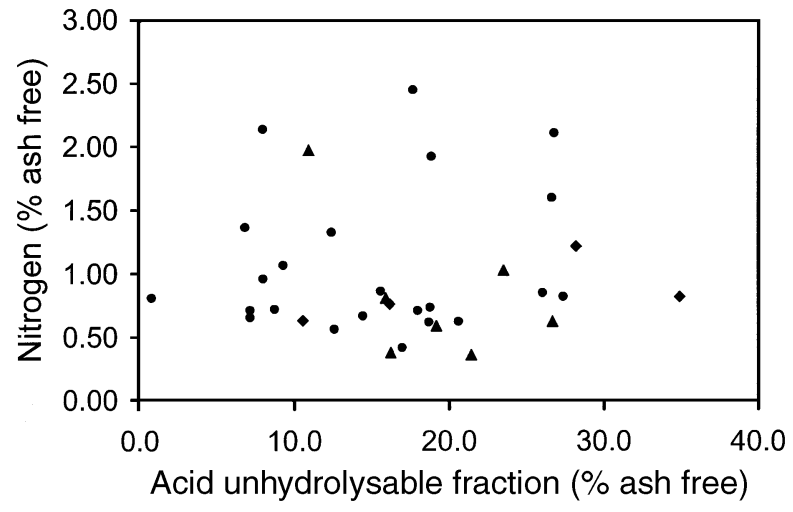

Fig. 3 Range of initial litter nitrogen and acid unhydrolysable fraction (traditionally referred to as lignin) concentrations of the litters used in Long-term Intersite Decomposition Experiment Team (LIDET). Standard leaves indicated by triangles and standard fine roots indicated by diamonds.

position rate (Olson, 1963; Wieder \& Lang, 1982; Harmon et al., 1999), particularly for short-term studies.

The second regression model used (Model 2) was also a simple negative exponential, but the solution was constrained so that $M_{02}$ (the $y$-intercept) ranged between $95 \%$ and $105 \%$. Its form was exactly the same as Model 1

$$
M_{t 2}=M_{02} \times \exp \left(-k_{2} \times t\right),
$$

We used this formulation because Model 1 will estimate an initial mass below $100 \%$ if there is an initial rapid drop in mass (Harmon et al., 1990, 1999). Conversely, if there is a lag before the onset of decomposition, Model 1 will estimate an initial mass above $100 \%$. Because we know that the mass started at $100 \%$, Model 2 is constrained by that knowledge.

The third regression model used (Model 3) was a simple negative exponential with an asymptote

$$
M_{t 3}=M_{03} \times \exp \left(-k_{3} \times t\right)+S_{03},
$$

where $M_{t 3}$ is the percent ash-free mass remaining, $M_{03}$ is the initial ash-free mass of material subject to loss, $S_{03}$ is the asymptote, $t$ is time in years, and $k_{3}$ is the decomposition rate constant. This model represents a two-phase decomposition process in which the second phase is completely stable. It implies that there is a fraction of the initial litter that either does not decompose or that new material is formed in the decomposition process that cannot decompose over the time period of observation. Although the model appears to contain three parameters, it has in fact two, because $M_{03}$ and $S_{03}$ sum to $100 \%$ and an estimate of one can be used to derive the other.

The fourth regression model used (Model 4) was also a simple negative exponential with an asymptote, but with $M_{04}$ and $S_{04}$ constrained to be within the range of
95-105\% of original mass

$$
M_{t 4}=M_{04} \times \exp \left(-k_{4} \times t\right)+S_{04}
$$

This model has the same biological meaning as Model 3 and although Model 3 should constrain the initial mass to be $100 \%$, we used Model 4 to assure that this was the case.

The fifth regression model used (Model 5) was a dual negative exponential

$$
M_{t 5}=M_{\mathrm{f} 05} \times \exp \left(-k_{\mathrm{f} 5} \times t\right)+M_{\mathrm{s} 05} \times \exp \left(-k_{\mathrm{s} 5} \times t\right),
$$

where $M_{t 5}$ is the percent ash-free mass remaining, $M_{\mathrm{f} 05}$ is the initial ash-free mass of fast material, $k_{\mathrm{f}}$ is the decomposition rate constant of this fast material, $M_{\mathrm{s} 05}$ is the initial ash-free mass of slow material, $k_{\mathrm{s} 5}$ is the decomposition rate constant of this slow material, and $t$ is time in years. This model has been used to capture decomposition dynamics in which two different fractions of organic matter are conceived to exist simultaneously, one that decays quickly and the other more slowly, each of which is controlled by its own rate constant. This model has previously been shown to capture the initial rapid loss of material followed by a transition to a slower rate observed in some short-term studies (Blair et al., 1990; Harmon et al., 1990, 1999).

We used nonlinear regression (SAS PROC NLIN with the DUD method) to estimate the parameters of the models (SAS Institute, 1999, SAS Companion for the Microsoft Windows Environment, Version 8, Cary, NC). We avoided removing all except the most obvious outliers from the raw dataset. Means of the percent ash-free mass remaining were calculated for each combination of standard litter and site for a total of 234 cases. Note that although theoretically there could be 243 cases ( 27 sites $\times$ nine litters), some of the cases were compromised by extreme outliers and/or missing data and were not analyzed. While it was possible to use linear regression models with logarithmic transformation to estimate parameters for Models 1 and 2, this was not possible for the remaining models. We therefore chose to use a uniform method of parameter estimation. In cases where we constrained the initial mass-related parameters, we set bounds for the total initial mass to 95-105\% given that variation in replicate samples was approximately 5\%. For all the other parameters, we started the 'search grid' of possible parameter values used by the DUD iterative process based on the range of decomposition rate constants observed by earlier analysis of the first 5 years of data (Gholz et al., 2000). If the convergence criteria of the iterative analysis procedure were not met, we readjusted the search grid in terms upper and lower limits and the initial search interval. 
This usually resulted in convergence, and in the cases where parameters were estimated using both searches, the parameters were extremely close (i.e. within 1\%). We estimated the $r^{2}$ of the nonlinear regressions by subtracting the residual sum of squares divided by the corrected total sum of squares from (1). Given the degrees of freedom of our analysis, we determined the number of equations that were significant at the $P<0.05$ level, which corresponds to an $r^{2}$ of 0.85 or greater.

\section{Evaluating the biological realism of models}

Once the parameters were estimated, we compared the model predictions to the observed data for each species and site. Rather than use $r^{2}$ as the sole index of how well the model fit the observed data, we compared the model predictions to the key biological performance criteria that the initial mass must start at $100 \%$ (Fig. 4). Our intent was to determine in how many cases each model matched or was biologically appropriate; one might think of this as a biologically vs. a statistically determined evaluation. In the case of Model 1, if the initial mass estimated by a regression of mass transformed to natural logarithms was statistically less than $<100 \%$ based on a one-tailed $t$-test, then a two-component loss pattern was indicated, and the model was scored as not matching. We also counted the number of cases in which the initial mass was predicted to be $<95 \%$, a value based on the typical level of variation expected in the mass remaining. In the case of Model 2, we expected that if a slow fraction exists, this model would tend to over estimate mass in the early stages and underestimate the mass in the later stages of decomposition. This model was scored as not matching if there was a significant and positive time-related trend in the nonlinear regression residuals as indicated by a significant negative $y$-intercept and a positive slope. In the cases of Models 3 and 4, we also used a regression of the residuals vs. time to test biological realism. The biological realism of the model would be questionable if
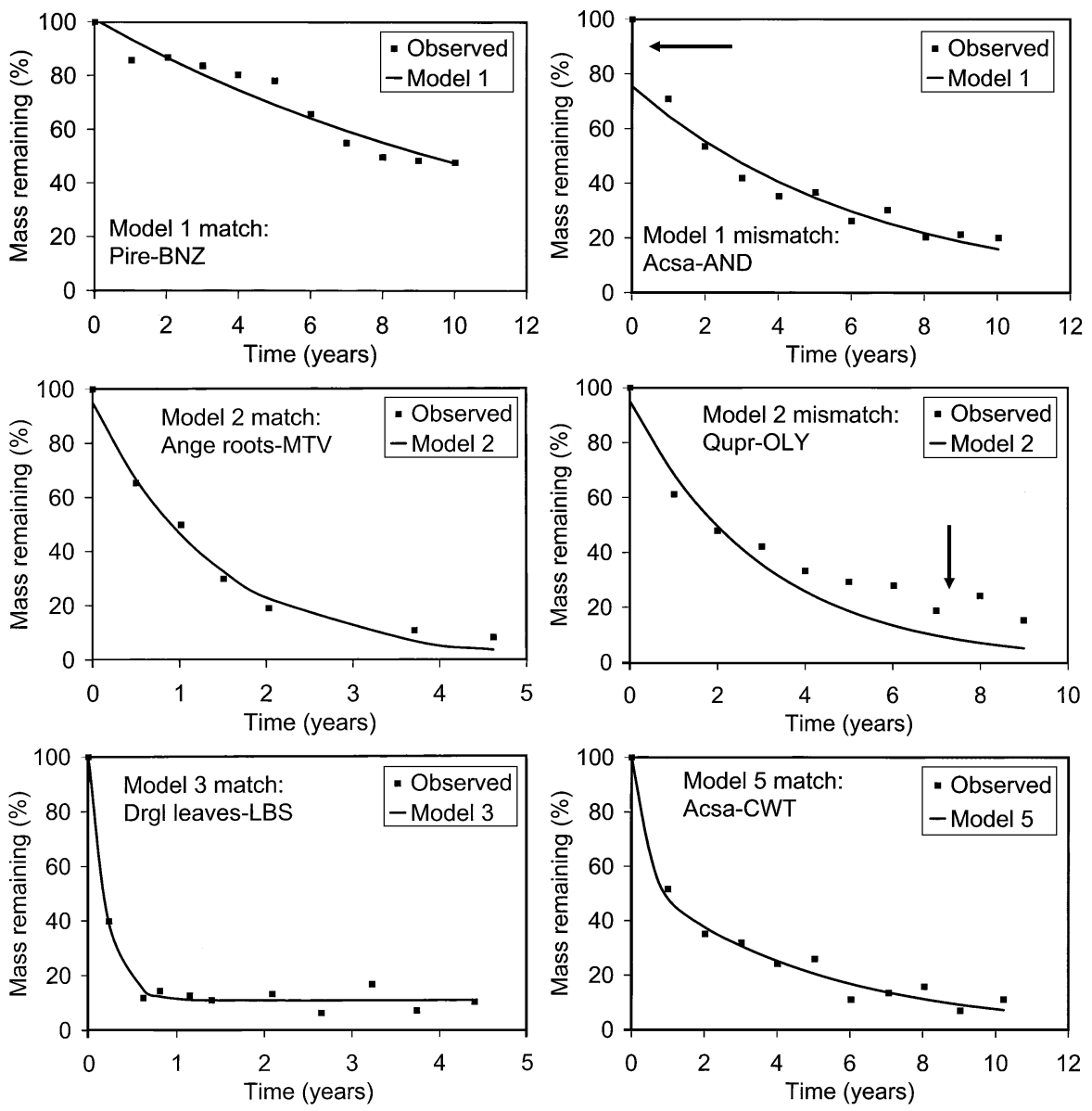

Fig. 4 Examples that matched and mismatched biological performance criteria of models. The criteria differed for the models. For example, for Model 1 we examined the initial mass estimate, but for Model 2 we looked for consistent underestimates in the later stages of decomposition. The arrows indicate the mismatches with observations. 
the regression of residuals was significant with a positive $y$-intercept and a negative slope. This would indicate mass continued to decline, but Models 3 or 4 predicted an asymptote. For Model 5, we considered two possible types of biological mismatches using the regression of the residuals vs. time. If the mass loss data actually indicated an asymptote, then Model 5 should tend to underestimate remaining mass in the later observations. This would be indicated by a negative $y$ intercept and a positive slope of the residual regression. If the mass loss data followed a simple negative exponential pattern, then Model 5 should overestimate remaining mass in the later observations. This would be indicated by a positive $y$-intercept and a negative slope to the residual regression.

\section{Estimating long-term integrated decomposition rates}

A disadvantage of using models with two components (i.e. Models 3-5) is the difficulty in directly estimating a long-term, average rate of decomposition. This is because the decomposition rate continuously changes over time. We derived a long-term integrated, weighted average decomposition rate by using the predicted mass remaining for Model 5 at time steps of 0.1 years. The sum of these masses over time represents the theoretical accumulation of litter that one would expect given a constant input and the modeled decomposition curve. By then assuming that this represented the steady-state mass (where the input and output fluxes are equal) and that the input was 100 units of mass (i.e. our models were expressed in percent mass remaining), we calculated the time integrated average decomposition rate $k_{\mathrm{I}}$ using the method of (Olson, 1963)

$$
k_{\mathrm{I}}=100 / M_{\mathrm{ss}},
$$

where $k_{\mathrm{I}}$ is the time integrated average decomposition rate constant, and $M_{\mathrm{ss}}$ is the estimated steady-state mass of litter. We used various times of up to 200 years to check if the estimate of $k_{\mathrm{I}}$ had become time invariant (i.e. an indication the predicted steady-state mass had been reached). We did not use Models 3 or 4 for this estimate because the integral of this function linearly increases once the asymptotic phase is reached; hence there is no steady-state solution.

\section{Evaluating the late, slow phase}

In addition to fitting regressions to match the temporal trends in decomposition, we approximated the amount and rate of decomposition of the kinetically defined slow phase. We used two methods to estimate the amount of slowly decomposing material that the models identified. In the first, we used the asymptote estimated by nonlinear regression. In our second test, we averaged the last four data points for each site/litter combination based on the assumption that this represented the midpoint of material in the later phases of decomposition. This method is likely to overestimate the amount of slow phase material if this phase is not completely reached within the time period covered by the last four data points.

We used two methods to estimate the decomposition rate of the slow phase material. The first was to use the mass specific decay rate $\left(k_{05}\right)$ for the slow fraction of Model 5. The second was to use the rate of decomposition estimated by Model $1\left(k_{01}\right)$ for the last four data points, after removing all the cases in which a simple negative exponential model biologically fit the data because these provided no evidence for a slow fraction.

\section{Results}

\section{Final mass remaining}

Despite the decade long duration, considerable litter mass remained in some cases after the experiment concluded. The minimum $(0.3 \%)$ and maximum (79.7\%) mass remaining were found at North Inlet and Arctic Lakes, respectively (Table 3). However, there was considerable range within these two sites. For example, Arctic Lakes had a minimum of $32.3 \%$, while North Inlet had a maximum of $58 \%$ mass remaining at the last measurement. The degree species differed was indicated in the differences between the maximum and minimum final remaining mass; this ranged between $18 \%$ at LaSelva Biological Station and $65 \%$ at Jornada.

\section{Evaluating the models}

Model 1: the negative exponential. For all litter types and sites, estimates of $k_{1}$ for the negative exponential (Model 1) ranged from 0 to 3.471 year $^{-1}$ and averaged 0.238 year $^{-1}$. Values of 0 for $k_{1}$ did not indicate that there was no decomposition at all; in this particular case, $M_{01}$ was $57 \%$ of initial mass, indicating a rapid initial loss followed by minimal decomposition. This reveals a shortcoming in Model 1 for representing such a wide range of litter $\times$ site combinations. Nonlinear regressions using this model produced $r^{2}$-values that ranged from $<0.01$ to 0.99 , with a mean of 0.78 . The model developed from nonlinear regression predicted over $85 \%$ of the variation in $48 \%$ of the cases (indicating they were significant), and therefore this model appears to be able to predict decomposition dynamics of many cases adequately. For the natural logarithm transformed regression, the single exponential model was significant $(P<0.05)$ for $87 \%$ of the cases, indicating that our 
Table 3 The mean final percent mass remaining at the end of the experiment for sites and species

\begin{tabular}{|c|c|c|c|c|c|c|c|c|c|}
\hline \multirow[b]{3}{*}{ Site code } & \multicolumn{9}{|c|}{ Species and litter type } \\
\hline & $\begin{array}{l}\text { Acer } \\
\text { saccharum }\end{array}$ & $\begin{array}{l}\text { Andropogon } \\
\text { gerardi }\end{array}$ & $\begin{array}{l}\text { Drypetes } \\
\text { glauca }\end{array}$ & $\begin{array}{l}\text { Drypetes } \\
\text { glauca }\end{array}$ & $\begin{array}{l}\text { Quercus } \\
\text { prinus }\end{array}$ & $\begin{array}{l}\text { Thuja } \\
\text { plicata }\end{array}$ & $\begin{array}{l}\text { Triticum } \\
\text { aestivum }\end{array}$ & Pinus spp. ${ }^{*}$ & $\begin{array}{l}\text { Pinus } \\
\text { spp.* }\end{array}$ \\
\hline & Leaf & Root & Leaf & Root & Leaf & Root & Leaf & Leaf & Root \\
\hline AND & 19.98 & 19.04 & 5.89 & 15.60 & 20.28 & 25.99 & 20.59 & 21.92 & 44.13 \\
\hline ARC & 32.33 & 50.03 & 36.47 & 64.82 & 36.11 & 45.89 & 46.00 & 63.83 & 79.71 \\
\hline BCI & 6.92 & 12.58 & 2.88 & 17.52 & 9.09 & 15.83 & 8.38 & 46.35 & 55.66 \\
\hline BNZ & 30.87 & 35.92 & 32.62 & 44.91 & 34.23 & 45.24 & 27.09 & 47.71 & 65.09 \\
\hline BSF & 50.32 & 40.18 & 24.00 & 49.27 & 49.00 & 50.87 & 34.00 & 64.77 & 55.64 \\
\hline CDR & 35.38 & 14.60 & 13.28 & 4.78 & 29.02 & 21.87 & 3.77 & 23.48 & 31.79 \\
\hline CPR & 41.29 & 21.00 & 27.17 & 25.04 & 31.09 & 73.45 & 34.97 & 44.26 & 66.00 \\
\hline CWT & 11.04 & 11.60 & 2.64 & 11.81 & 4.86 & 20.42 & 7.98 & 9.47 & 42.60 \\
\hline GSF & 52.16 & 18.33 & 35.40 & 10.71 & 41.17 & 57.11 & 15.18 & 64.87 & 45.63 \\
\hline HBR & 23.14 & 10.88 & 9.49 & 21.77 & 14.94 & 23.48 & 8.78 & 13.04 & 44.54 \\
\hline HFR & 10.42 & 16.42 & 11.14 & 19.83 & 12.03 & 18.57 & 13.19 & 26.00 & 47.59 \\
\hline JRN & 0.11 & 25.07 & 30.06 & 28.22 & 37.05 & 27.72 & 6.33 & 7.69 & 65.03 \\
\hline JUN & 30.59 & 27.44 & 18.14 & 46.26 & 28.17 & 43.41 & 30.79 & 40.46 & 60.56 \\
\hline KBS & 7.29 & 5.51 & 5.19 & 37.41 & 9.03 & 30.61 & 2.64 & 44.63 & 25.91 \\
\hline KNZ & 31.57 & 10.13 & 5.37 & 21.96 & 54.36 & 47.14 & 19.04 & 26.85 & 33.18 \\
\hline LBS & 13.20 & 5.15 & 9.97 & 11.58 & 18.35 & 15.36 & 16.20 & 19.26 & 23.47 \\
\hline LUQ & 15.97 & 9.39 & 7.16 & 17.93 & 12.11 & 22.10 & 9.58 & 28.34 & 40.28 \\
\hline LVW & 52.10 & 36.69 & 31.04 & 37.29 & 49.23 & 53.12 & 29.47 & 64.51 & 63.06 \\
\hline MTV & 16.25 & 8.10 & 9.24 & 8.06 & 17.20 & 27.21 & 10.65 & 35.60 & 18.31 \\
\hline NIN & 9.44 & 53.66 & 0.59 & 58.32 & 4.49 & 10.87 & 0.03 & 8.20 & 52.11 \\
\hline NLK & 50.99 & 55.66 & 45.69 & 63.96 & 68.45 & 68.49 & 65.46 & 75.22 & 78.47 \\
\hline NWT & 36.06 & 46.89 & 37.59 & 39.44 & 47.89 & 69.88 & 43.90 & 56.39 & 70.52 \\
\hline OLY & 19.48 & 18.32 & 8.29 & 22.99 & 15.22 & 16.11 & 6.36 & 27.01 & 37.57 \\
\hline SEV & 35.74 & 33.52 & 58.76 & 36.00 & 64.61 & 66.17 & 50.89 & 52.36 & 70.23 \\
\hline SMR & 63.60 & 9.42 & 30.83 & 15.76 & 49.25 & 50.87 & 32.51 & 48.53 & 32.41 \\
\hline UFL & 16.55 & 3.29 & 2.76 & 8.36 & 8.89 & 21.50 & 6.28 & 28.24 & 34.81 \\
\hline VCR & 20.63 & 50.25 & 4.67 & 50.09 & 8.63 & 41.19 & 0.07 & 47.08 & 62.26 \\
\hline
\end{tabular}

*The species of Pinus used varied by site and root vs. leaf.

nonlinear significance test was conservative. A comparison to the observations with respect to our 'biological criteria' indicated that Model 1 had an initial mass $<95 \%$ for $73 \%$ of the total cases examined $(N=234)$, indicating the possibility of a biologically unrealistic model. A one-tailed $t$-test indicated that in $35 \%$ of the cases the $y$-intercept was significantly $(P<0.05)$ lower than 100\%; given our degrees of freedom for the regressions, this is likely to be a conservative estimate.

The degree to which cases matched our criterion for Model 1 depended on the litter species and type incubated. Analyzed at the level of species and type of litter only Pinus resinosa roots did not have an initial mass that was significantly lower than $100 \%$. To illustrate how well the models matched the data we graphed two contrasting litter types: Pinus and Drypetes leaves; see Fig. 5. For $P$. resinosa leaves, the major mismatch between predictions and observations was that the initial mass was predicted to be $<100 \%$, although there were also cases in which a lag was evident. For Drypetes leaves, the simple negative exponential best fit the middle stages of decomposition and generally underestimated the initial mass as well as overestimated losses in the later stages of decomposition. Analysis at the level of sites indicated that for 13 of the 27 sites, the initial mass was not significantly different than $100 \%$; these were typically drier sites (Central Plain-Short Grass Steppe, Jornada, and Sevilleta) or those with a dry season at the start of the experiment (Barro Colorado Island).

Model 2: constrained negative exponential. For all litter types and sites, estimates of $k_{2}$ for the negative exponential constrained to have an initial mass of $100 \%$ (Model 2) ranged from 0 to 3.159 year $^{-1}$ and averaged 0.400 year $^{-1}$. The $k_{2}$ of 0 year ${ }^{-1}$ was for Pinus elliottii roots at Niwot Ridge, a site that generally had 

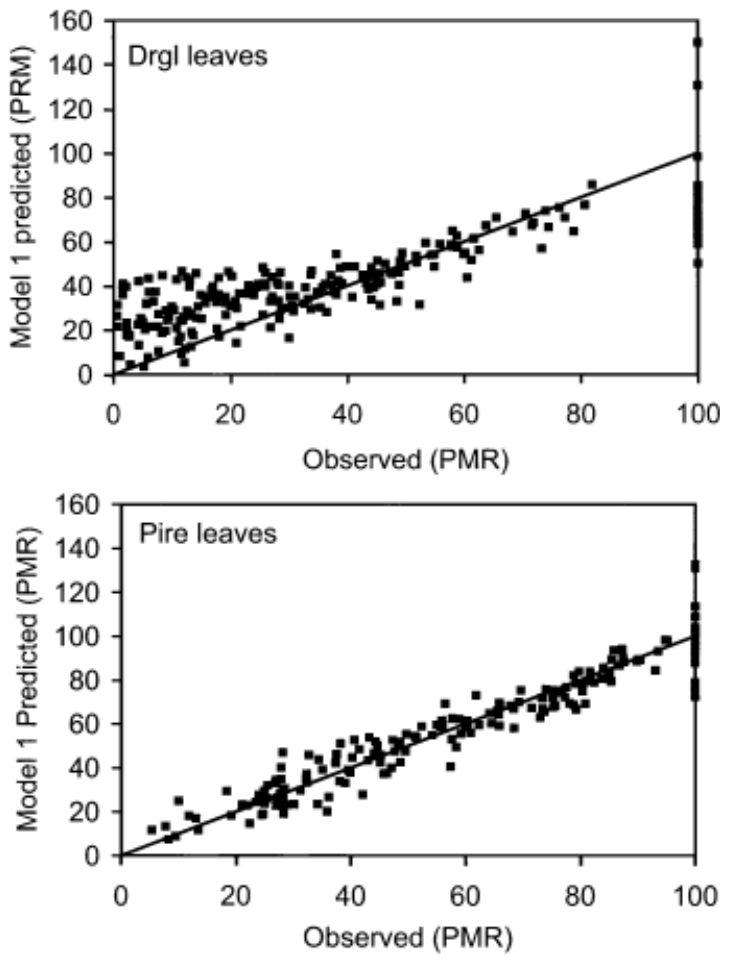

Fig. 5 Remaining mass predicted by the simple negative exponential regression (Model 1) vs. the observed data for two representative litter types. PMR is percent mass remaining; the $1: 1$ line is shown.

$k_{2}>0.10$ year $^{-1}$. Nonlinear regressions using this model produced $r^{2}$-values that ranged from $<0.01$ to 0.99 , with 0.67 as the mean.

This model predicted over $85 \%$ of the variation in $30 \%$ of the cases, a lower proportion than for the simple negative exponential model. However, we selected this model because of its diagnostic potential; it should deviate from the observations in a predictable manner by underestimating mass in later stage of decomposition if there was a slow phase of decomposition. An analysis of the residuals from the nonlinear regressions indicated that in $52.4 \%$ of the cases that there was a significant relationship between the residual and time, with $43.6 \%$ having a negative $y$ intercept and a positive slope. This would indicate Model 2 tended to underpredict mass in the later stages of decomposition for many cases.

As with Model 1, the degree to which this model biologically matched depended on the species, with $P$. resinosa roots being the only litter type that did not have a significant residual regression. In the case of $P$. resinosa leaves, adding the constraint to the negative exponential removed the mismatch between predictions and observations for initial mass (Fig. 6). For Drypetes leaves, Model 2 generally underestimated
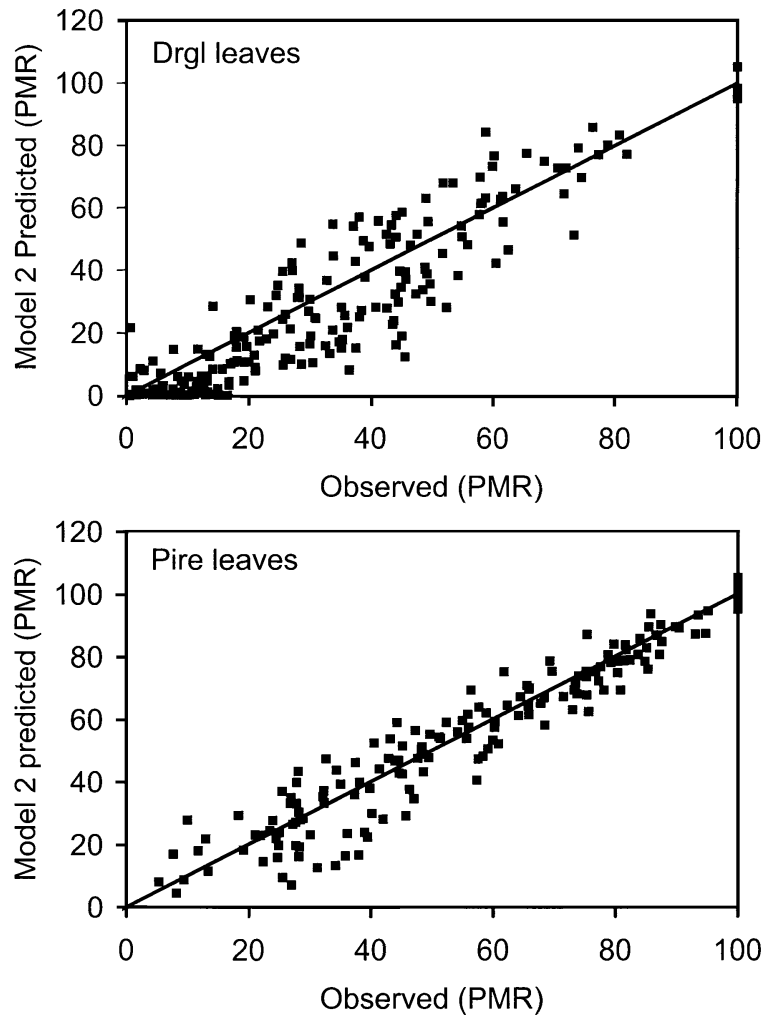

Fig. 6 Remaining mass predicted by the simple negative exponential regression with initial mass constrained to $100 \%$ (Model 2) vs. the observed data for two representative litter types. PMR is percent mass remaining; the $1: 1$ line is shown.

the mass in the later stages of decomposition, but the initial mass constraint imposed allowed this model to match the earlier stages of decomposition better. Also as with Model 1, there was a pattern of variation in the adequacy of Model 2 among sites, with drier sites more likely to conform to Model 2 than wetter sites.

Models 3 and 4: negative exponential model with an asymptote. For all litter types and sites, estimates of $k_{3}$ for the negative exponential with an asymptote (Model 3) ranged from 0.072 to 4.98 year $^{-1}$ and averaged 0.721 year $^{-1}$. Nonlinear regressions using this model produced $r^{2}$-values that ranged from $<0.01$ to 0.99 with a mean of 0.77 . This model was statistically significant and predicted over $85 \%$ of the variation in $46 \%$ of the cases, thus predicting decomposition dynamics about as well as Model 1. A striking result was that regression of residuals was significant in $11.9 \%$ of the cases examined and that a positive $y$-intercept and negative slope occurred in only $4 \%$ of the cases. This would indicate this model matched our biological criteria for $\sim 95 \%$ of the total cases examined $(N=234)$. 

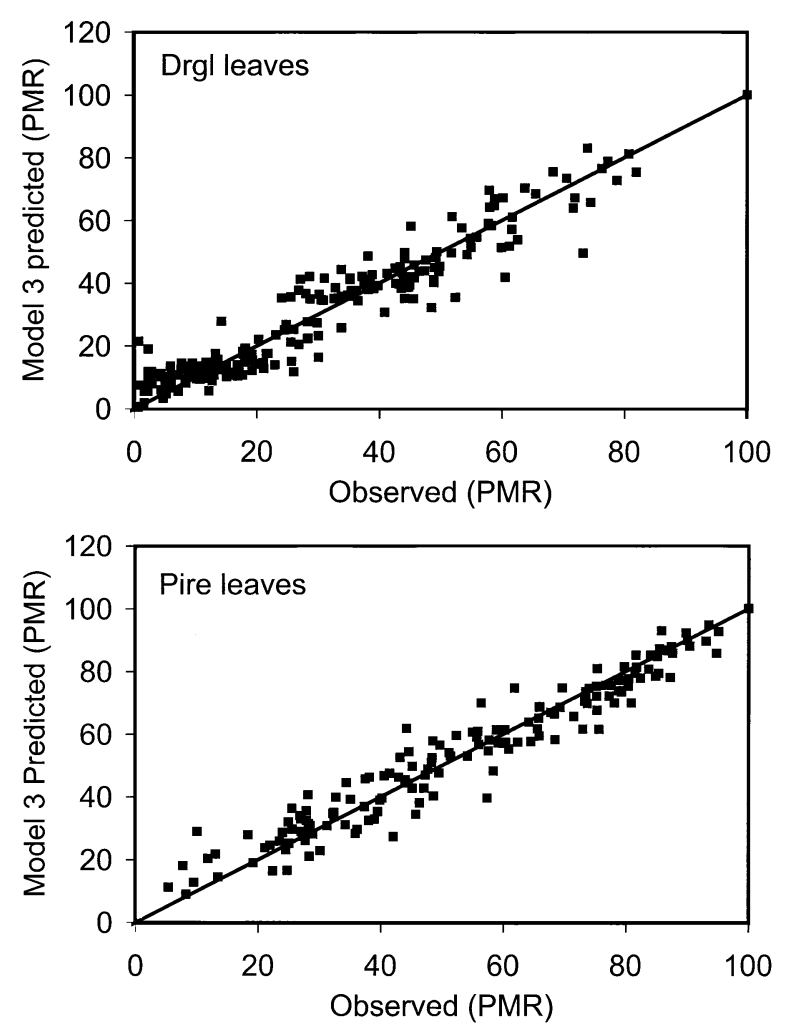

Fig. 7 Remaining mass predicted by the negative exponential and asymptotic regression (Model 3) vs. the observed data for two representative litter types. PMR is percent mass remaining; the $1: 1$ line is shown.

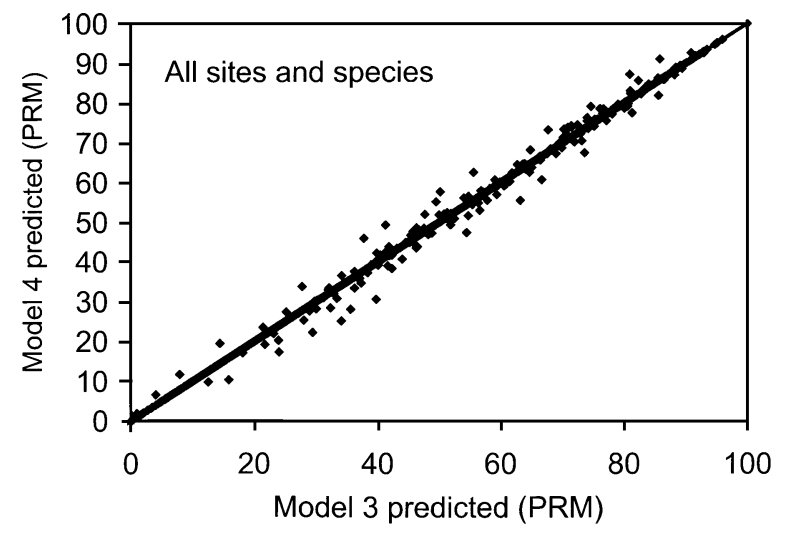

Fig. 8 Relationship between predictions of Models 3 and 4 . Both models are negative exponential and asymptotic regressions, but Model 4 has the initial mass constrained to 100\%. PMR is percent mass remaining; the 1:1 line is shown.

In the case of both P. resinosa and Drypetes leaves, the major mismatch between predictions and observations was that there was a tendency for mass in the later phases of decomposition at first to be underestimated and then to be overestimated as decomposition progressed (Fig. 7). This pattern would be expected if
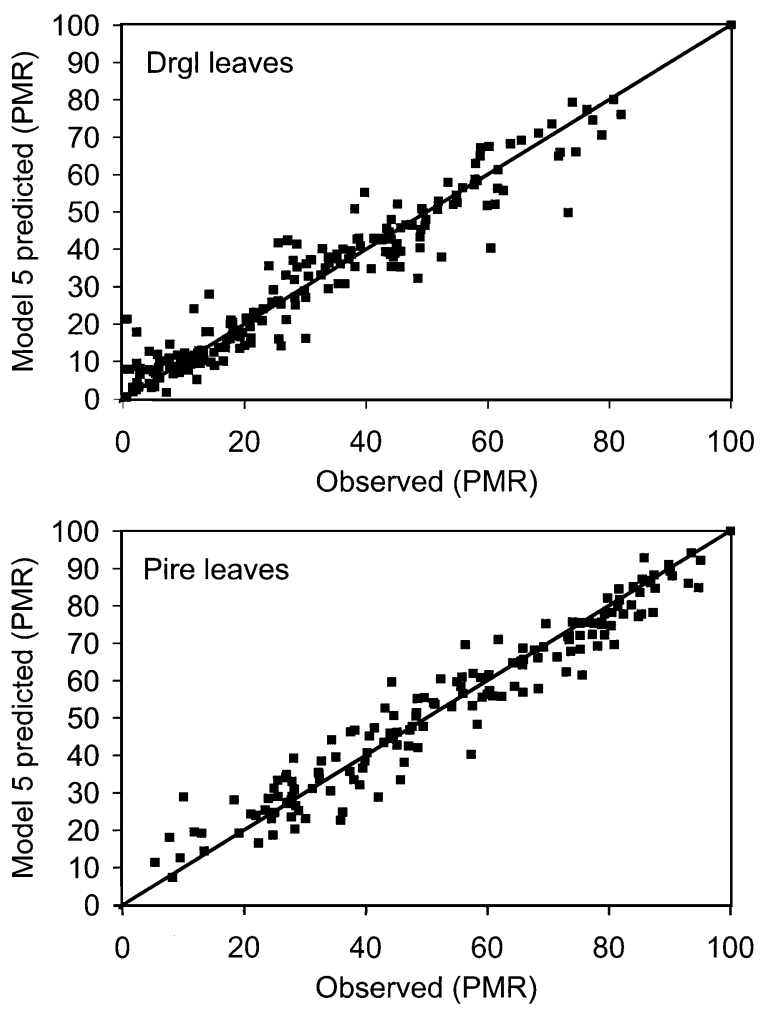

Fig. 9 Remaining mass predicted by the dual negative exponential regression (Model 5) vs. the observed data for two representative litter types. PMR is percent mass remaining; the $1: 1$ line is shown.

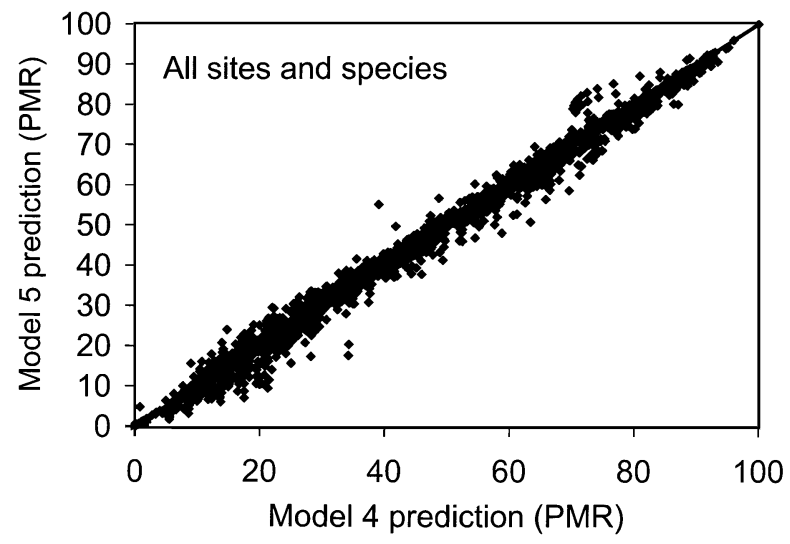

Fig. 10 Relationship between predictions of Model 4 (with asymptote) and Model 5 (dual exponential) for all species and sites. PMR is percent mass remaining; the $1: 1$ line is shown.

some decomposition occurred during the slow phase, because the asymptote represents an average of these two time periods.

The results for Model 4 were very similar to those of Model 3 and therefore a detailed description of that analysis is omitted (Fig. 8). 
Model 5: the dual exponential regression model. The dual exponential regression (Model 5) produced $r^{2}$-values that ranged from 0.14 to 0.999 with a mean of 0.77 for all litter types and sites. This model was statistically significant and predicted over $85 \%$ of the variation in $59 \%$ of the cases. Based on purely statistical criterion this model predicts decomposition dynamics best across the range of litter types and sites we analyzed. Consistent with this finding, the regression of residuals against time indicated significant regressions in $10.2 \%$ of the cases. For $0.4 \%$ of the cases, a negative $y$-intercept and positive slope was found, indicating an underestimation of mass remaining in the later stages of decomposition. This would indicate an asymptotic phase. For $2 \%$ of the cases, the regression had a significant positive $y$-intercept and a negative slope, indicating the mass remaining was overestimated as would be expected if the mass loss pattern was a negative exponential. This would indicate that Model
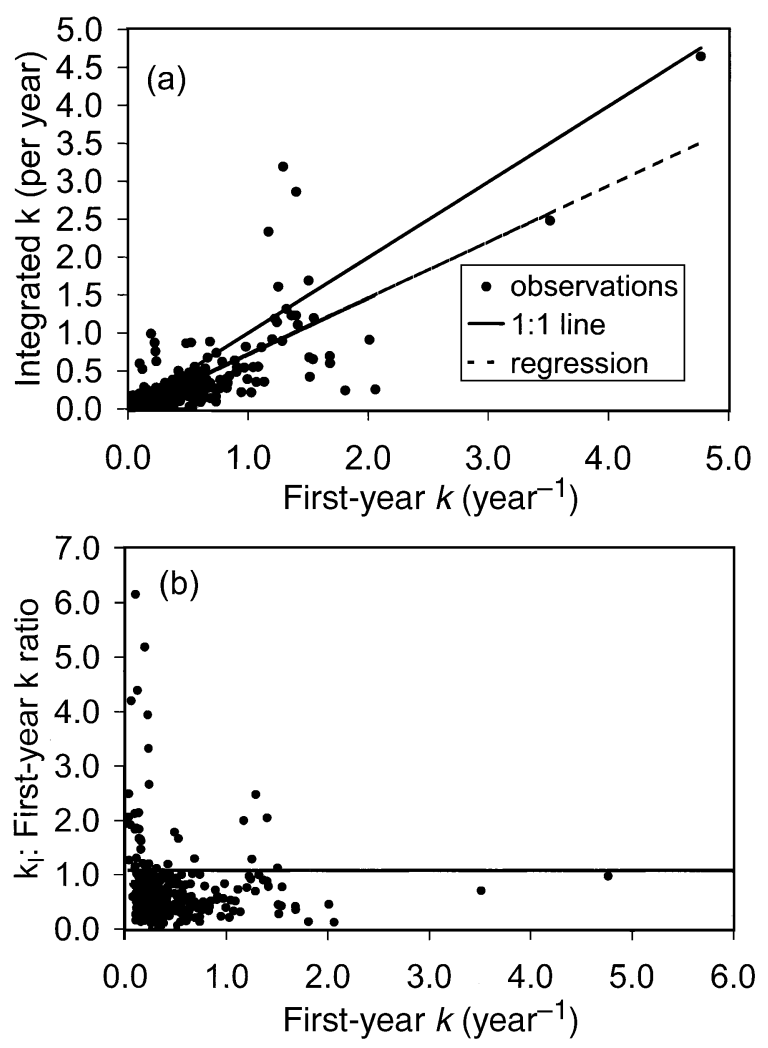

Fig. 11 Relationship of the integrated, weighted average decomposition rate vs. that estimated from 1 year of decomposition. (a) Comparison of the integrated vs. the 1-year decomposition rate. The regression equation is $Y=-0.03+$ $0.75 \times X, r^{2}=0.59$. (b) Ratio of the integrated $k$ and the 1 -year $k$ vs. the 1-year decomposition rate. The horizontal line indicates a ratio of 1 , the expected case when there was no slow phase of decomposition.
5 matched biological criteria for $\sim 97 \%$ of the 234 cases examined.

For both P. resinosa and Drypetes leaves, the major mismatch between predictions and observations was that there was a tendency for mass in the later phases of decomposition to be overestimated by the model (Fig. 9). We expected this to occur if decomposition in the later phases was faster than indicated by $k_{\mathrm{s} 5}$ (i.e. the rate constant controlling the slow fraction) during this period. Despite slight differences, the predictions of Models 4 and 5 were very similar (Fig. 10). Based on $r^{2}$-values and the degree they biologically match with the cases examined, it would be difficult to objectively select between the two models. In other words, we found that overall patterns of decay over the 10-year period could be characterized equally well if late-stage decay were represented by an asymptote or by a second component, with a lower rate constant.

\section{Estimates of long-term integrated decomposition rate}

The estimates of the long-term average or integrated decomposition rate $\left(k_{\mathrm{I}}\right)$ ranged from 0.017 to 4.653 year $^{-1}$ and averaged 0.353 year $^{-1}$. These values are considerably lower than the first-year decomposition rate constant, which ranged from 0.034 to 4.766 year $^{-1}$ and averaged 0.51 year $^{-1}$. Thus while not all cases exhibited a slow phase of decomposition, it was prominent enough that, on average long-term integrated decomposition rate constant was roughly $70 \%$ of the short-term decomposition rate constant.

A regression of the integrated $k$ against the 1-year $k$ across all 234 cases indicated that the former was $75 \%$ of the latter on average (Fig. 11a); however, in $18 \%$ of the cases the integrated $k$ was higher than the 1-year $k$ indicating a possible lag in decomposition (Fig. 11b). The ratio of the integrated $k$ to the 1 -year $k$ was most likely to exceed 1 when the 1-year $k$ dropped below 0.5 year $^{-1}$. For the majority of cases it appears that $1-$ year estimates are higher than long-term decomposition rate constants, indicating that models using short-term rates will underestimate litter stores.

\section{Evaluating the slow phase: decomposition rate and amount of material}

The range in slow decomposition rate constants, as indicated by the mass loss during the last four time points for the species that did not conform to the simple negative exponential model was $0-1.34$ year $^{-1}$, with a mean of 0.221 year $^{-1}$. This wide range is largely related to differences in site conditions. For example, the range at the coldest site, Arctic, was 0.014-0.104 year ${ }^{-1}$, 
whereas the range at one of the warmest sites (LaSelva) was $0.23-0.80$ year $^{-1}$. There were also differences among species, but the range of averages among species was smaller than sites: 0.059 year $^{-1}$ for $P$. elliottii fine roots to 0.47 year $^{-1}$ for Triticum aestivum as compared with a site range of $0.057-1.073$ year $^{-1}$ (at Arctic and Luquillo, respectively).

Across all sites and litter types the range of slow fraction decomposition rates $\left[k_{\mathrm{s} 5}\right.$ in Eqn (6)] estimated from Model 5 indicated that the decomposition rate constant of the slow material ranged from 0 to 1.46 year $^{-1}$ and averaged 0.139 year $^{-1}$. These rates were lower than that estimated for the last four data points, which is consistent with our finding that, in inspecting the curve fits of Model 5 for biological realism, we noted that Model 5 tended to overestimate mass remaining in the latest stage of decomposition. The slow fraction decay-constants from Model 5 were also considerably lower than the estimates of decomposition rate constants for the 'fast' fraction, which ranged from 0.06 to 76 year $^{-1}$ and averaged 9.73 year $^{-1}$. This result indicates that in many cases the fast phase of decomposition was completed within a year. The species averages of the decomposition rate of the slow fraction of litter $\left(k_{s 5}\right)$ ranged from 0.06 year $^{-1}$ for $P$. elliottii fine roots to 0.178 year $^{-1}$ for Quercus prinus leaves. The site averages of $k_{\mathrm{s} 5}$ ranged from 0.042 year $^{-1}$ for Loch Vale to 0.687 year $^{-1}$ for Luquillo.

Although the values of $k_{\mathrm{f} 5}$ and $k_{\mathrm{s} 5}$ [Eqn (6)] provide no direct information about the amount of slow-decaying substrate, our method of fitting regressions did fit the constants $M_{\mathrm{f} 05}$ and $M_{\mathrm{s} 05}$ [Eqn (6)] representing the portions of initial mass subject to decomposition at each of the two rate constants. The amount of slow material $\left(M_{\mathrm{s} 05}\right)$ appeared to be a function of both site characteristics and substrate quality. Similarly, Models 3 and 4 provided estimates of slow fraction masses $S_{03}$ [Eqn (4)] and $S_{04}$ [Eqn (5)], respectively. Based on these estimates of asymptotic mass, the slow fraction was equivalent to $0-73 \%$ of the initial mass across our range in litter types and sites. Those regression estimates with little to no slow fraction material were cases where a simple negative exponential model closely matched the temporal pattern (e.g. P. resinosa leaves). The average of the asymptotic mass was $32 \%$ of the initial mass, with the species average ranging from a low of $15 \%$ for $T$. aestivum to a high of $45 \%$ for P. elliottii fine roots. The range among site averages was even wider, ranging from $3.8 \%$ at Luquillo to $51 \%$ at Loch Vale. In general, as the climatic favorability for decomposition of a site increased, the amount of slow material decreased. Similar patterns were revealed by the average of the last four observations of mass remaining, which ranged among all the cases from $2.8 \%$ to $80 \%$ of ash-free mass.
The range in averages for species was from $17 \%$ for Drypetes leaves to $52 \%$ for $P$. elliottii fine roots. The range among site averages was somewhat wider with $13 \%$ at LaSelva and up to $56 \%$ at Loch Vale.

\section{Discussion}

\section{Evaluating models of decomposition}

We selected a range of regression models that had meaningful biological interpretations and that have been applied in the past. Our primary purpose of using these models was not to find the 'best' model, as that is likely to depend on the type of litter, the environment, and the length of time of the measurements. For some species and substrates (e.g. Pinus leaves) a simple negative exponential model appears to match biological criteria particularly well. For others (e.g. Drypetes leaves), a simple negative exponential model does not often match the reasonable biological expectation that the initial mass start at $100 \%$. For short-term studies that end before the slow fraction becomes evident, a single negative exponential model will most likely fit observations (although not if there are large initial rapid losses of very labile fractions).

It is tempting to use the single negative exponential model as it has the most convenient equation for simple parameterization. However, our analysis shows that a more complex model (Model 5) provides the most generally acceptable set of curve fits to data across a wide range of litters and sites. Moreover, Model 5, the dual exponential, is the most general case and simplifies to the other models. When a slow fraction is not present, it simplifies to Models 1 or 2. Alternatively, when the slow fraction has an undetectable rate of decomposition, it simplifies to Models 3 or 4 which includes an asymptote representing a stable fraction. On this basis, we recommend that a dual exponential model is the logical starting place for any analysis of long-term decomposition patterns. Models 3, 4, and 5 appear to fit the data equally well in terms of statistical measures of fit such as $r^{2}, P$-values, or mean square error. Information not present in the LIDET dataset, such as direct measures of the rate of decomposition of the slow fraction would be needed to distinguish among them.

Other models, particularly simulation models, might be even better than those considered here. Given our sample size for each litter type and site combination, we could not use linear regression methods to estimate parameters for a three-component model. However, using a simulation modeling framework, this is possible and there are indications that this improves the match with observed data (Coûteaux et al., 1998; Adair et al., 2008). Biologically this probably does provide increased 
realism because it could capture a rapid loss of labile material, an intermediate stage dominated by structural compounds but still undergoing significant decomposition (Coûteaux et al., 1995), and a slow phase or limit value (Aber et al., 1990; Berg, 2000a, b). It may also be advantageous to consider a continuous range of substrate quality (Ågren \& Bosatta, 1987) or the generation of slower decomposing secondary material by decomposers in more mechanistic models.

\section{Estimating long-term decomposition rates}

The observation that in many cases a simple negative exponential model cannot be used has implications for how species are compared and how decomposition data are used. With a simple negative exponential model the relative ranking of species is time invariant. However, with either an asymptote or a dual exponential model it is possible that the relative ranking is a function of time, making one-time comparisons of species problematic. Our integrated, weighted average rate constant $\left(k_{\mathrm{I}}\right)$ provides a time invariant ranking of species and sites. This integrated rate is also most useful for aggregated ecosystem models that consider a single overall pool of litter vs. models that track cohorts of litter (Pastor \& Post, 1986), or ones that track fast and slow fractions separately (Parton et al., 1987, 1994; Currie \& Aber, 1997).

In $18 \%$ of the cases the integrated $k$ was higher than the 1-year $k$ : six sites (Central Plains-Shortgrass Steppe, Jornada, Juneau, North Temperate Lakes, Santa Margarita, and Sevilleta) accounted for the majority (i.e. $82 \%$ ) of these cases. With the exception of Juneau and North Temperate Lakes, these were dry sites in which colonization by decomposers might have been slow or dependent on the arrival of a wet year. Alternatively, these are sites where photodegradation is highly likely and slow initial biological decomposition might be followed by more rapid physical degradation (Parton et al., 2007). In the case of North Temperate Lakes, the shorter timeframe of the experiments at that site have might have precluded the development of a slower phase of decomposition. For Juneau, the incorporation of the litterbags into the deep moss layers at that site might have caused decomposition rates to increase over time by increasing litter moisture content.

In addition to being slower than short-term decomposition rate constants, it is possible that long-term decomposition processes are under a different set of controls than those of initial decomposition. W.S. Currie et al. (unpublished data) examined the degree climate and substrate quality indices correlated with long-term decomposition rate constants. While climatic indices, such as CDI and AET, and substrate quality indices, such as, lignin, $\mathrm{N}$, acid-hydrolysable fraction, and tannin content, were correlated to $k_{\mathrm{I}}$, these correlations were much weaker than for short-term decomposition rate constants. This implies that as decomposition advances, differences in litter types and places tend to decrease.

\section{Evaluating the presence of a slow phase}

The inter-relationship of the mathematical models we analyzed yields insight into when and where there is a slow fraction. It must be borne in mind that the slow phase is operationally defined. One cannot actually measure it directly because chemically it represents a poorly understood, complex mixture of materials (Swift et al., 1979; Melillo et al., 1989; Kögel-Knabner, 2002). If we define the slow phase as causing a deviation from the simple negative exponential model, then we can conclude that in many cases, some slow material influenced the temporal trend in mass remaining. However, there are also many cases in which a slow fraction need not be invoked to explain the temporal pattern of mass loss. While it would be ideal if deviations from the single exponential model could be predicted from substrate quality or site conditions, we did not find any obvious relationships that could be used in a predictive model. As suggested in W.S. Currie et al. (unpublished data) there may be interactions between the litter in the bags and the surrounding litter that may influence the pattern and rate of decomposition.

We observed a wide range in the amount of slow material that is estimated across the LIDET experiment. It appears to be lower at sites with environments more conducive to rapid decomposition, but the differences among species remain relatively constant. This may indicate that the rate at which slow material is decomposed is a function of the site environment, while the amount of slow-material precursor compounds initially present is a property of the species of litter. W.S. Currie et al. (unpublished data) found that climate indices, such as CDI and AET, and substrate quality indices, such as lignin, acid-hydrolysable fraction, and tannin, were correlated to the size of the slow pool. However, the coefficients of determination for these regressions was $<21 \%$, supporting the lack of clear trends found in our preliminary analysis.

Although the latter stages of decomposition have been referred to as a stable phase (Melillo et al., 1989; Aber et al., 1990), decomposition appears to be detectable over the time-span of a decade. Our analysis indicates a decomposition rate of the slow fraction of $>0.01$ year $^{-1}$, with most of the estimates being an order of magnitude higher. This is in contrast to the decomposition rates of mineral soil organic matter, which 
tends to have decomposition rate constants of $<0.01$ year $^{-1}$ (Gaudinski et al., 2000; Trumbore, 2000). Therefore, one might conceive of the slow litter material as being the precursor to soil organic matter that is complexed with mineral material, with the slow component of litter having a faster rate of mass loss than soil organic matter.

Our estimates of decomposition rates of the slowly decomposing material are relatively crude. A more controlled study, starting with a known quantity of this material and examining its dynamics using stable isotope enrichment would greatly improve understanding of the factors controlling the degradation of this complex material. Better chemical and kinetic characterization of the nature of the slow material might also provide insights into how this material is formed during decomposition. If on one hand, the slow material is simply a residual recalcitrant fraction initially present in the litter (e.g. as proposed by Coûteaux et al., 1995), one would predict that the input is controlled by the type of litter and its rate of decomposition controlled by the site physical environment and biota. If on the other hand, this material is formed by decomposers from the original material (as proposed by Kögel-Knabner, 2002), then both the input and decomposition of this material are likely to be controlled by the site physical environment and biota.

There is an important global-scale implication of the presence or absence of a later, slowly decomposing fraction in plant litter. Global estimates of litter stores have rarely been directly estimated as in the case of mineral soil carbon (Post et al., 1982; Jobbagy \& Jackson, 2000), although the work of Matthews (1997) is an exception. Estimates of pool sizes are typically derived from litterfall rates combined with estimates of decomposition rate constants. Our study indicates that shortand long-term decomposition rates are not similar, and in the majority of cases $(82 \%)$ the average, long-term decomposition-rate constant is lower than the 1-year decomposition rate constant. A rough global impact on the difference in estimates of litter stores can be derived by dividing the input flux by the decomposition rate constant (Olson, 1963). This indicates that if 1 -year decomposition rate constants are used in these estimates, litter pool sizes are likely to be underestimated by at least $34 \%$ relative to those using long-term rate constants. Our analysis indicates that the negative exponential model is appropriate for the many species and site combinations examined (27-65\% depending on the test used). Further, our estimates of an integrated decomposition rate constant, representing a weighted average, are on average $75 \%$ that of 1-year decomposition rate constants, an observation consistent with the presence of a slower phase of decomposition. While our study has focused on the biological degradation of litter, there are many systems where fire removes a large fraction of organic material added to the system. Sites and litter types that exhibited an asymptotic pattern of litter decomposition, may accumulate considerably less litter than our equations indicate if fires are frequent. A more detailed analysis of the degree to which litter stores have been underestimated and relative balance of biotic vs. abiotic (i.e. fire) losses is therefore warranted.

\section{Acknowledgements}

This study would not have been possible without the dedicated efforts of many people. We are indebted to their efforts to collect and process samples, as well as to provide background information on their site characteristics and climate. Dr Richard Reeves of NCEAS (the National Center for Ecological Analysis and Synthesis) assisted with the programming for the nonlinear regression analysis. We also wish to thank Drs John Aber, Jerry M. Melillo, and Knute Nadelhoffer for organizing the 1989 workshop at Woods Hole that developed the original plan for LIDET. In addition to the numerous grants that supported personnel at the individual sites, this study was supported by grants from the National Science Foundation (DEB-9108329, DEB-9806493). These synthesis efforts were supported by funds from the LTER Network Office, the Kaye and Ward Richardson Endowment and the Bullard Fellowship Program of Harvard University. This work was conducted as part of the Decomposition working Group supported by NCEAS, a Center funded by the NSF (DEB-0072909), the University of California at Santa Barbara, and the State of California. Dr John Pastor and two other reviewers are thanked for their helpful comments on the drafts of this manuscript.

\section{References}

Aber JD, Melillo JM, McClaugherty CA (1990) Predicting longterm patterns of mass loss, nitrogen dynamics, and soil organic matter formation from initial fine litter chemistry in temperate forest ecosystems. Canadian Journal of Botany, 68, 2201-2208.

Adair EC, Parton WJ, DelGrosso SJ, Silver WL, Hall SA, Harmon ME, Hart SC (2008) A simple three pool model accurately describes patterns of long term, global decomposition in the Long Term Intersite Decomposition Experiment Team (LIDET) data set. Global Change Biology, 14, 2636-2660.

Ågren GI, Bosatta N (1987) Theoretical analysis of the longterm dynamics of carbon and nitrogen in soils. Ecology, 68, 181-1189.

Berg B (2000a) Initial rates and limit values for decomposition of Scots pine and Norway spruce needle litter: a synthesis for $\mathrm{N}$-fertilized forest stands. Canadian Journal of Forest Research, 30, 122-135.

Berg B (2000b) Litter decomposition and organic matter turnover in northern forest soils. Forest Ecology and Management, 133, 13-22.

Berg B, Ekbohm G, McClaugherty CA (1984) Lignin and hollocellulose relations during long-term decomposition of some forest litters: long-term decomposition in a Scots pine forest IV. Canadian Journal of Botany, 62, 2540-2550. 
Berg B, McClaugherty CA (2003) Plant Litter: Decomposition, Humus Formation, Carbon Sequestration. Springer-Verlag, New York.

Berg B, McClaugherty CA, Virzo De Santo A, Johnson D (2001) Humus buildup in boreal forests effects of litterfall and its $\mathrm{N}$ concentration. Canadian Journal of Forest Research, 31, 988-998.

Blair JM, Parmelee RW, Beare MH (1990) Decay rates, nitrogen fluxes, and decomposer communities of single- and mixedspecies foliar litter. Ecology, 71, 1976-1985.

Bridson JN (1985) Lipid fraction in forest litter: early stages of decomposition. Soil Biology and Biochemistry, 17, 285-290.

Bunnell FL, Tait DEN (1977) Microbial respiration and substrate loss. II. A model of the influences of chemical composition. Soil Biology and Biochemistry, 9, 41-47.

Bunnell FL, Tait DEN, Flanagan PW, Van Cleve K (1977) Microbial respiration and substrate loss. I. A general model of the influences of abiotic factors. Soil Biology and Biochemistry, 9, 33-40.

Chen H, Harmon ME, Sexton J, Fasth B (2002) Fine root decomposition and $\mathrm{N}$ dynamics in coniferous forests of the Pacific Northwest of USA. Canadian Journal of Forest Research, 32, 320-331.

Coûteaux MM, Bottner P, Berg B (1995) Litter decomposition, climate and litter quality. Trends in Ecology and Evolution, 10, 63-66.

Coûteaux MM, McTiernan KB, Berg B, Szuberla D, Dardenne P, Bottner P (1998) Chemical composition and carbon mineralization potential of Scots pine needles at different stages of decomposition. Soil Biology and Biochemistry, 30, 583-595.

Currie WS, Aber JD (1997) Modeling leaching as a decomposition process in humid montane forests. Ecology, 78, 1844-1860.

Dubois MK, Gilles KA, Hamilton JR, Rebers PA, Smith F (1956) Colorimetric method for determination of sugars and related substances. Annals of Chemistry, 28, 350-356.

Edmonds RL (1984) Long-term decomposition and nutrient dynamics in Pacific silver fir needles in western Washington. Canadian Journal of Forest Research, 14, 395-400.

Effland MJ (1977) Modified procedure to determine acid-insoluble lignin in wood and pulp. Tappi, 60, 143-144.

Fogel R, Cromack K Jr (1977) Effect of habitat and substrate quality on Douglas-fir litter decomposition in western Oregon. Canadian Journal of Botany, 55, 1632-1640.

Gaudinski JB, Trumbore SE, Davidson EA, Zheng S (2000) Soil carbon cycling in a temperate forest: radiocarbon-based estimates of residence times, sequestration rates and partitioning of fluxes. Biogeochemistry, 51, 33-69.

Gholz HL, Wedin D, Smitherman S, Harmon ME, Parton WJ (2000) Long-term dynamics of pine and hardwood litter in contrasting environments: toward a global model of decomposition. Global Change Biology, 6, 751-765.

Hagerman AE (1988) Extraction of tannin from fresh and preserved leaves. Journal of Chemical Ecology, 14, 453-462.

Harmon ME, Baker GA, Greene SE, Spycher G (1990) Early decomposition of leaf litter in a Picea-Tsuga forest, Olympic National Park, Washington, USA. Forest Ecology and Management, 31, 55-66.
Harmon ME, Nadelhoffer KJ, Blair JM (1999) Measuring decomposition, nutrient turnover, and stores in plant litter. In: Standard Soil Methods for Long Term Ecological Research (eds Robertson GP, Bledsoe CS, Coleman DC, Sollins P), pp. 202240. Oxford University Press, New York.

Haslam E (1989) Plant Polyphenols: Vegetable Tannins Revisited. Cambridge University Press, Cambridge, MA.

Howard PJA, Howard DM (1974) Microbial decomposition of tree and shrub litter. I. Weight loss and chemical composition of decomposing litter. Okios, 25, 314-352.

Jansson PE, Berg B (1985) Temporal variation of litter decomposition in relation to simulated soil climate: long-term decomposition in a Scots pine forest. Canadian Journal of Botany, 63, 1008-1016.

Jobbagy EB, Jackson RB (2000) The vertical distribution of soil organic carbon and its relation to climate and vegetation. Ecological Applications, 10, 423-436.

Kirschbaum MUF (2000) Will changes in soil organic carbon act as a positive or negative feedback on global warming? Biogeochemistry, 48, 21-51.

Kögel-Knabner I (2002) The macromolecular organic composition of plant and microbial residues as inputs to soil organic matter. Soil Biology and Biochemistry, 34, 139-162.

Kurcheva GF (1960) The role of invertebrates in the decomposition of oak litter. Pedology (Leningrad), 4, 16-23.

Lousier JD, Parkinson D (1978) Chemical element dynamics in decomposing leaf litter. Canadian Journal of Botany, 56, 27952812.

Lousier JD, Parkinson D (1979) Organic matter and chemical element dynamics in a aspen woodland soil. Canadian Journal of Forest Research, 9, 449-463.

Magill AH, Aber JD (1998) Long-term effects of experimental nitrogen additions on foliar litter decay and humus formation in forest ecosystems. Plant and Soil, 203, 301-311.

Matthews E (1997) Global litter production, pools, and turnover times: estimates from measurement data and regression models. Journal of Geophysical Research, 102D, 18,77118,800 .

McClaugherty CA, Pastor J, Aber JD, Melillo JM (1985) Forest litter decomposition in relation to soil nitrogen dynamics and litter quality. Ecology, 66, 266-275.

Meentemeyer V (1978) Macroclimate and lignin control of litter decomposition rates. Ecology, 59, 465-472.

Melillo JM, Aber JD, Linkins AE, Ricca A, Fry B, Naddelhoffer K (1989) Carbon and nitrogen dynamics along the decay continuum: plant litter to soil organic matter. In: Ecology of Arable Land (eds Clarholm M, Bergstrom L), pp. 53-62. Kluwer Academic Publishers, Dordrecht.

Melillo JM, Aber JD, Murtore JF (1982) Nitrogen and lignin control of hardwood leaf litter decomposition dynamics. Ecology, 63, 621-626.

Melillo JM, Naiman RJ, Aber JD, Linkins AE (1984) Factors controlling mass loss and nitrogen dynamics of plant litter decaying in northern streams. Bulletin of Marine Science, 35, 341-356.

Minderman G (1968) Addition, decomposition, and accumulation of organic matter in forests. Journal of Ecology, 56, 355-362. 
Moore TR, Trofymow JA, Siltanen M, Prescott CCIDET Working Group (2005) Patterns of decomposition and carbon, nitrogen,and phosphorus dynamics of litter in upland forest and peatland sites in central Canada. Canadian Journal of Forest Research, 35, 133-142.

Moorhead DL, Currie WS, Rastetter EB, Parton WJ, Harmon ME (1999) Climate and litter quality controls on decomposition: an analysis of modeling approaches. Global Climate Change, 13, $575-589$.

Obst JR, Kirk KT (1988) Isolation of Lignin. Advances in Enzymology, 161, 3-12.

Olson JS (1963) Energy stores and the balance of producers and decomposers in ecological systems. Ecology, 44, 322-331.

Parton WJ, Ojima DS, Cole CV, Schimel DS (1994) A general model for soil organic matter dynamics: sensitivity to litter chemistry, texture, and management. Soil Science Society of America Special Publication, 39, 147-167.

Parton WJ, Schimel DS, Cole CV, Ojima DS (1987) Analysis of factors controlling soil organic matter levels in Great Plains Grasslands. Soil Science Society of America Journal, 51, 1173-1179.

Parton WJ, Silver WL, Burke IC et al. (2007) Global-scale similarities in nitrogen release patterns during long-term decomposition. Science, 315, 361-364.

Pastor J, Post WM (1986) Influence of climate, soil moisture, and succession on forest carbon and nitrogen cycles. Biogeochemistry, 2, 3-27.

Post WM, Emanuel W, Zinke PJ, Stangenberger AG (1982) Soil carbon pools and world life zones. Nature, 298, 156-159.

Ryan MG, Melillo JM, Ricca A (1990) A comparison of methods for determining proximate carbon fractions of forest litter. Canadian Journal of Forest Research, 20, 166-171.

Silver WL, Miya RK (2001) Global patterns in root decomposition: comparisons of climate and litter quality effects. Oecologia, 129, 407-419.
Singh JS, Gupta SR (1977) Plant decomposition and soil respiration in terrestrial ecosystems. Botanical Review, 43, 449-528.

Swift MJ, Heal OW, Anderson JM (1979) Decomposition in Terrestrial Ecosystems. University of California Press, Berkeley.

Tappi (1976) Alcohol-benzene and dichloromethane solubles in wood and pulp. Tappi Official Standard T204.

Tappi (1981) Water solubility of wood and pulp. Tappi Official Standard T207.

Trofymow JA, Moore TR, Titus B et al. (2002) Rates of litter decomposition over 6 years in Canadian forests: influence of litter quality and climate. Canadian Journal of Forest Research, 32, 789-804.

Trumbore S (2000) Age of soil organic matter and soil respiration: radiocarbon constraints on belowground C dynamics. Ecological Applications, 10, 399-411.

Vogt KA, Grier CC, Vogt DJ (1986) Production, turnover, and nutrient dynamics of above- and belowground detritus of world forests. Advances in Ecological Research, 15, 303-377.

Wardle DA, Zachrisson O, Hörnberg G, Gallet C (1997) The influence of island area on ecosystem properties. Science, 277, 1296-1299.

Wieder RK, Lang GE (1982) A critique of the analytical methods used in examining decomposition data obtained from litter bags. Ecology, 63, 1636-1642.

Witkamp M, Crossley DA Jr (1966) The role of arthropods and microflora in breakdown of white oak litter. Pedobiologia, 6 , 292-303.

Witkamp M, Olson JS (1963) Breakdown of confined and nonconfined oak litter. Oikos, 14, 138-147.

Yahdjian LO, Sala E, Austin A (2006) Differential controls of water input on litter decomposition and nitrogen dynamics in the Patagonian Steppe. Ecosystems, 9, 128-141. 